\title{
IMPORTING CORRUPTION CULTURE FROM OVERSEAS: EVIDENCE FROM CORPORATE TAX EVASION IN THE UNITED STATES
}

\author{
Jason M. DeBacker \\ Bradley T. Heim \\ Anh Tran \\ Working Paper 17770 \\ http://www.nber.org/papers/w17770 \\ NATIONAL BUREAU OF ECONOMIC RESEARCH \\ 1050 Massachusetts Avenue \\ Cambridge, MA 02138 \\ January 2012
}

The views expressed herein are those of the authors and do not necessarily reflect the views of the National Bureau of Economic Research, U.S. Department of the Treasury or the Office of Tax Analysis.

NBER working papers are circulated for discussion and comment purposes. They have not been peerreviewed or been subject to the review by the NBER Board of Directors that accompanies official NBER publications.

(C) 2012 by Jason M. DeBacker, Bradley T. Heim, and Anh Tran. All rights reserved. Short sections of text, not to exceed two paragraphs, may be quoted without explicit permission provided that full credit, including $\odot$ notice, is given to the source. 
Importing Corruption Culture from Overseas: Evidence from Corporate Tax Evasion in the United States

Jason M. DeBacker, Bradley T. Heim, and Anh Tran

NBER Working Paper No. 17770

January 2012

JEL No. D73,H25,M14

\begin{abstract}
This paper studies how cultural norms and enforcement policies influence illicit corporate activities. Using confidential IRS audit data, we show that corporations with owners from countries with higher corruption norms engage in higher amounts of tax evasion in the U.S. This effect is strong for small corporations and decreases as the size of the corporation increases. In the mid-2000s, the United States implemented several enforcement measures which significantly increased tax compliance. However, we find that these enforcement efforts were less effective in reducing tax evasion by corporations whose owners are from countries with higher corruption norms. This suggests that cultural norms can be a challenge to legal enforcement.
\end{abstract}

Jason M. DeBacker

Department of the Treasury

jason.debacker@gmail.com

Bradley T. Heim

School of Public and Environmental Affairs

Indiana University

1315 E 10th St

Bloomington, IN 47405

heimb@indiana.edu
Anh Tran

1315 E. 10th St

SPEA Room 410J

Bloomington, IN 47405

trananh@indiana.edu 


\section{Introduction}

According to the Government Accountability Office, 68 percent of foreign corporations operating in the U.S. did not pay a single dollar in federal income tax between 1998 and 2005; during this period, almost two-thirds of U.S. firms also avoided paying tax (GAO, 2008). This is despite the fact that these corporations made trillions of dollars in sales revenue at the time. Though much of this is due to legal tax avoidance, each year, the federal budget loses hundreds of billions of dollars due to illegal tax noncompliance (IRS, 2006). In countries with higher levels of corruption and weaker adherence to laws, this problem may be even worse. It is estimated that tax evasion costs the world's poorest countries around US\$900bn each year in lost tax revenue (Mathiason, 2008).

This paper studies the link between corruption norms overseas and tax evasion in the U.S. Specifically, we ask whether foreign controlled corporations from more corrupt countries are more likely to evade U.S. taxes. We answer this question by linking the results of over 25,000 IRS corporate tax audits from 1996 to 2007 with corruption measures from the foreign owner's country of residence. Our paper connects the corporate tax evasion literature with research on the role of cultural norms in illegal activities.

The economics literature on tax evasion is small but expanding. Its basic framework for analysis dates back to Allingham and Sandmo (1972), which was built on a seminal model of crime by Becker (1968). In this framework, taxpayers choose an optimal of tax evasion given the level of penalty, probability of getting caught, and their own level of risk aversion. ${ }^{1}$ To analyze the role of corporate governance in tax evasion, this framework has been embedded in a principal-agent structure. Using this approach, Slemrod (2004) argues

\footnotetext{
1 This framework has been extended to incorporate different issues for individual tax evasion. For a review of this literature see Andreoni, Erard and Feinstein (1998) or Sandmo (2005).
} 
that small firms tend to behave more like individuals than do large firms. This is because an owner of a small firm may make tax reporting decisions directly. In large firms the tax planning and reporting decisions are often delegated. In this case owners must provide incentives for their tax directors to evade. Crocker and Slemrod (2005) demonstrate that a firm's principal could alter compensation contracts with his agents to induce tax evasion on his behalf, though such arrangements might not always be the case. Further, Desai and Dharmapala (2006) point out that high-powered incentives for agents may not lead to higher tax evasion for the principal if tax evasion and diversion of rents are complementary activities.

Empirical tests of theoretical models of corporate tax evasion have been limited due to a general lack of data. Only a handful of studies measure tax evasion using differences between income reported to the IRS and to other parties, or IRS audit data. Desai and Dharmapala (2006) creatively use the difference between income reported to the IRS and investors (not attributable to accounting accruals) to show a negative relationship between incentive compensation and tax sheltering among corporations with poor governance. In contrast, Hanlon, Mills and Slemrod (2007) use audit data to find evidence that strong executive compensation incentives are associated with increased tax noncompliance. However, the authors do not find evidence for a relationship between commonly used measures of corporate governance and tax evasion, as Desai and Dharmapala (2006) do. Hanlon, Mills and Slemrod also suggest that corporate tax noncompliance relative to total income (or total assets) may be U-shaped. That is, tax evasion is high among small businesses but decreases among medium-sized firms, then increases again among large firms. Hanlon, Mill and Slemrod find that private firms tend to engage in tax evasion more than 
public firms, who have the incentive to report higher profit. However, they treat this evidence as tentative.

While the economics literature focuses on the economic and financial motivations for tax evasion, there is an emerging literature on the role of culture in illegal activities. For example, a recent study examines illegal parking by United Nations' diplomats in New York City. Fisman and Miguel (2007) find that the corruption norms in the diplomats' home countries strongly influence their propensity to engage in illegal parking in NYC. The stationing of United Nations' diplomats in NYC provides a natural experiment for testing the role of cultural norms because diplomats from different countries (with different norms) face the same set of economic incentives regarding illegal parking in one city. While there is not yet similar research relating to tax evasion, cultural factors have been argued to be important in shaping behavior in this illicit activity. Frey (1997) proposes that taxpayers pay taxes because of both extrinsic motivation (e.g., worries about penalties for tax evasion) and intrinsic motivation (e.g., the willingness to contribute to a public good). The latter is shaped by cultural parameters such as personal values and social norms, and there is some evidence for this influence from survey data. Slemrod (2003) finds that survey responders who said they trust the government tend also report paying higher taxes (see also Torgler (2003) and Hanousek and Palda (2004)). Joulfaian (2000) shows that executives who underreport their personal taxable income also tend to run firms that have higher incidences of tax noncompliance. It is, however, unclear whether this relationship is driven by cultural norms or personal risk preferences.

In this paper we test the influence of corruption norms on corporate tax evasion, an important illegal behavior exercised by corporations. Fisman and Miguel (2007) found that social norms influence illicit behavior by individuals, but the extent to which norms affect 
corporate behavior is an open question, both conceptually and empirically. On the one hand, social norms may affect corporations because they affect the individuals who control corporations. People who personally tolerate or participate in corruption may be likely to accept or encourage illegal activities collectively. On the other hand, corporations are institutions rationalized to maximize profit, and therefore they may be expected to respond only to institutional incentives such as audit probabilities and expected penalties. These opposing arguments motivate a test for the power of social norms in determining the behavior of economic organizations such as corporations.

We utilize a new dataset of 25,541 IRS audits of foreign-owned corporations for the 12 years from 1996 to 2007. Corporate tax evasion by foreign-owned corporations in the U.S. provides a natural experiment because it subjects firms with different home-country norms to the same legal and enforcement incentives in the United States. In these firms, foreign owners may handle tax filling directly (especially in small firms) or influence their tax staff (especially in large firms). This setting allows us to estimate the influence of homecountry corruption norms of a firm on its tax evasion behavior. We measure a firm's tax evasion using the ratio of IRS-determined tax deficiency over total income. The IRSdetermined tax deficiency is the amount of positive adjustment to the firm's tax liability following audit. ${ }^{2}$ Corruption norms in home countries are measured using the well-known Corruption Perception Index by Transparency International. Given the important role of firms' size (pointed out by Hanlon, Mills, and Slemrod (2007)), we examine the effect of corruption norms on tax evasion for different firms' size groups. Although the selection of

\footnotetext{
${ }^{2}$ Note that this is the IRS recommended adjustment and not the actual amount the tax payer remits after any appeals and/or legal proceedings. The line between tax evasion and tax avoidance is often ambiguous. We do not argue that the tax adjustment we use in this paper is strictly tax evasion, but it is perhaps the best measure for tax evasion available to date. Throughout the paper, we will use the terms tax adjustment, deficiency and evasion interchangeably.
} 
firms for auditing is not random, we are able to address this selection issue by using the Discriminant Information Function (DIF) score, which IRS computes to determine the likelihood of auditing change in tax liability following audit. The IRS then uses the DIF score in its audit selection decisions.

The results are straightforward. High corruption norms are strongly associated with increased tax evasion among small and medium firms. As the firms' size increases, this effect diminishes gradually. As an illustration, we find that a firm with annual revenue and total assets equal to the sample mean ( $\$ 20$ million and $\$ 50$ million, respectively) and with an owner from a country with Nigeria-level corruption, on average, exceeds a similar firm from Sweden in tax noncompliance by about $\$ 64,371$ (equivalent to about $8 \%$ of mean total corporation income tax for firms who evade). However, as firm assets become very large (above $\$ 102$ million), the difference in their tax evasion behavior becomes negligible. The association between corruption norms and tax deficiencies is quite robust to controlling for a number of possibly confounding covariates, including a country's GDP per capita, trade relations, distance from the United States, the firm's net income, and even country fixed effects. These results provide evidence supporting the view that cultural norms can shape corporate behavior, as well as the view that large corporations (which are likely to have more delegated tax reporting) attenuate the influence of individual norms.

Our paper also studies the effectiveness of enforcement policies aimed at corporate tax evasion. From 1996 to 2007, the United States implemented several measures to deal with corporate tax evasion. The Sarbanes-Oxley Act in 2002 required CEOs of publicly traded firms to sign off on their company's tax return and increased the penalties for noncompliance, while the introduction of Schedule M-3 on Form 1120 in 2004 required firms with more than $\$ 10$ million in total assets to provide much more detail on book-tax 
differences than previously. During the same period, the IRS also increased tax audit rates significantly in certain years and areas. Our estimates indicate that at least some of these enforcement efforts led to a significant decrease in tax evasion among foreign-controlled firms, but were less effective against this misbehavior by firms with owners from corrupt countries. The results indicate the resistance of corruption norms against legal enforcement.

Our paper proceeds as follows. In Section 2, we describe corporate income tax returns, the auditing process and the data we use. Section 3 presents our estimation of the effect of corruption on tax evasion. Section 4 reports the estimation of the impact of enforcement programs. Section 5 concludes.

\section{Data}

\subsection{Corporate audit, tax, and firm characteristics}

Corporations with operations or income in the United States are required to file Form 1120, the U.S. Corporation Income Tax Form, annually. On this form, the corporation's tax preparer reports to the Internal Revenue Service (IRS) the employer identification number (or EIN) of the corporation, and the amount of income, deductions, taxable income, and tax owed for the corporation in that tax year, among other items.

Attached to this form are a number of additional supporting schedules. The most important of these for the present study is Schedule $\mathrm{K}$, which collects descriptive information about the corporation. On this schedule, line 7 asks whether one foreign person owned at least $25 \%$ of the corporation ${ }^{3}$ at any time during the year. If the answer to

\footnotetext{
${ }^{3}$ Specifically, Schedule K asks whether the person owned at least $25 \%$ of the total voting power of all classes of the corporation's stock entitled to vote, or at least $25 \%$ of the total value of all classes of the corporation's stock.
} 
this question is yes, the corporation must report the percentage owned by that individual, and the owner's country of residence. ${ }^{4}$ We will refer to companies that answered yes on line 7 of Schedule K as a "foreign-controlled corporation."

Each year, about 2,000 returns of foreign-controlled corporations are selected for an examination, or audit. ${ }^{5}$ The IRS uses a formula that measures the likelihood that a change in tax liability will be found upon examination, or the Discriminant Information Function, to determine the probability of audit for each firm. Larger firms are much more likely to be audited than smaller firms. Approximately 0.8-1 percent of returns of small firms are selected. Among large firms, additional returns are selected for audit based on the characteristics of the firms. In total, approximately $15-20 \%$ of very large corporations' returns are selected. ${ }^{6}$

During the audit process, a team generally conducts an initial interview followed by a tour of the business. Subsequently, the audit team meets with the business to discuss the plan of the audit and the timeframe for the audit, request documents, and notify the business of proposed adjustments. The examiners then perform an investigation, and conclude whether any additional taxes and penalties are owed. If the team concludes additional amounts are owed, the taxpayer may either agree to pay the additional amounts, or submit an appeal. Once this is done, from the point of view of the audit team, the case is entered as being closed in the Audit Information Management System (AIMS).

\footnotetext{
${ }^{4}$ If there are multiple such owners, this information is reported for each owner. However, the IRS data we use only lists the information for the largest owner. Owners are any "person", by which the IRS means any controlling entity; individual, estate, trust, partnership, or corporation. The IRS does not collect data on entity type of the owner. For individual owners the foreign country code is the owner's country of residence. For other entities, the country code is that of the country in which the entity is incorporated, organized, created, or administered. In the case of a holding company that is part of a chain between a U.S. subsidiary or the ultimate foreign parent, the country data may be related to the holding company and not the ultimate parent. The data do not allow us to identify entities along such chains, only the immediate controlling entity.

${ }^{5}$ See http://www.irs.gov/pub/irs-drop/fy_2009_enforcement_results.pdf

${ }^{6}$ For additional information on how returns are selected for audit, see U.S. GAO (1995).
} 
To create the dataset used in this study, we begin with data from the IRS's Audit Information Management System. These data contain the results of all IRS corporate audits that were closed between 1996 and 2010. From this dataset, we pull the recommended change in tax after the audit. We will refer to this variable as the "Audit Adjustment" in what follows.

To the audit data, we merge corporate tax return data from the IRS's Compliance Data Warehouse (CDW). The CDW consists of variables from the universe of tax returns (both corporate and individual) filed from 1996 onward. From the corporate CDW, we draw tax return information for each firm-year that is present in the AIMS dataset, including variables denoting the tax year of the return, the EIN and company name, whether a company has a foreign owner with at least a $25 \%$ ownership share, and which country the largest foreign owner is from (to indicate a foreign controlled corporation). In addition, we use variables that identify the primary industry of the firm, total assets (which are taken from Item $\mathrm{D}$ on the front page of the 1120), and total income (which is line 11 on the front page of the 1120). Finally, we use an indicator for whether the firm claimed a foreign tax credit or filed Form 5471, showing that the firm has multinational operations.

To these data, we merge information from the Compustat North America and Compustat Global databases, which enable us to identify publicly traded firms. ${ }^{7}$

If we included all audited firms in our sample, the sample would be dominated by firms that are owned by U.S. citizens. Since this paper focuses on how corruption norms in foreign countries affects taxpaying in the United States, including all such firms might attenuate the estimated impact of our corruption variable. So, to focus on cross country variation in corruption norms outside the United States, we include a firm in our sample

\footnotetext{
${ }^{7}$ Compustat Global covers approximately $98 \%$ of the world's market capitalization. As a result, there may be some firms that we wrongly consider as non-public, but the number is likely to be quite small.
} 
only if the firm is observed to be foreign controlled at least one year during our sample period. ${ }^{8}$

\subsection{Cross-country data}

Corruption measures. We use the annual Corruption Perception Index (CPI) published by Transparency International as our primary measure of corruption of the owner's home country. Measuring the corruption level of a country is difficult and all current measures have certain advantages and drawbacks, although they tend to correlate strongly to each other. We chose the CPI because it is commonly acceptable and widely used in corruption research. This index is computed annually based on subjective evaluations of experts drawn from 16 surveys worldwide, and is used in a number of other studies ${ }^{9}$ (See Figure 1). Countries with higher levels of corruption have lower values on the 10-point CPI scale. To make interpretation easier, we reverse the CPI scale. Specifically, we subtract the CPI from 10 to obtain our corruption measure. ${ }^{10}$ Thus, in our analysis, a higher corruption index corresponds to higher levels of corruption.

As an alternative measure of corruption, we also use the World Bank's Control of Corruption Indicator. This aggregate indicator gathers opinion data from several surveys of firms, residents and experts in developed and developing country, and is also a popular measure of corruption in practical and academic studies.

Other country-level characteristics. To ensure that tax evasion is driven by the owner's home country's corruption norms and not economic incentives, we control for a number of additional country-level characteristics, using data from various sources. The GDP per

8 The resulting sample will include some U.S. owned firms, but only if ownership changed to or from a foreign national during our sample period.

${ }^{9}$ For example, see Fisman (2001), Djankov et al. (2002), and Barth et al. (2009).

10 Other studies have also reversed the CPI to make it more intuitive. For examples, see Fisman and Miguel (2007) and D’Souza (2010). 
capita data come from the World Bank's World Development Indicators, while distance to the U.S. is the weighted average distance between population centers in the country and the U.S., and is computed by the CEPII Research Center. Bilateral trade data come from the U.S. Census Bureau. Finally, data on foreign corporate tax rates and regimes comes from the OECD's Tax Database and the World Bank's World Development Indicators.

\subsection{Data sample and statistics}

To create the estimation sample, we perform a couple of additional sample cuts. First, we drop S corporations (which do not pay tax at the entity level), regulated investment companies (RICs), and real estate investment trusts (REITs) from our analysis, as these types of entities receive much different tax treatment than regular $\mathrm{C}$ corporations. Second, we exclude observations missing any variables used in the regression analysis.

Throughout, all nominal values are deflated to 2009 . To deal with outliers, all monetary variables are $90 \%$ Winsorized. Winsorization of the data is necessary to deal with outliers. The tax data we use are not edited in any way by IRS and thus data entry and calculation errors by the filers or the IRS agent keying in the data are not uncommon. ${ }^{11}$

Table 1 presents sample means for the variables used in our regression analysis. The first column presents means for all companies in the sample, the second column presents means for corporations with owners from OECD countries, and the third column presents means for corporations with owners from non-OECD countries. Adjustments average almost $\$ 88,776$ among all foreign-controlled firms, and on average amount to about $0.67 \%$ of total income. Approximately $12.1 \%$ of all firms are publicly traded, and $28.4 \%$ of all firms have multinational operations (indicated by claiming a foreign tax credit or ownership of a controlled foreign corporation on Form 5471). Wholesale, manufacturing and finance form

\footnotetext{
11 Table 6 below shows the robustness of the results to various levels of Winsorization.
} 
the three largest industries in our sample, followed by professional firms, retail, transport and information.

[Table 1 about here]

Table 2 presents summary statistics on audit adjustment amounts. Our sample contains 25,541 firm-year observations of firms who underwent an audit between 1996 and 2007. ${ }^{12}$ Adjustments following audits include recommended changes to taxes, interest and penalties. Among all audited firms, 42.6\% had a positive audit adjustment, with a mean adjustment of $\$ 208,290$, while $16.4 \%$ had a negative audit adjustment, with a mean of $\$ 53,370 .^{13}$

[Table 2 about here]

In the raw data, there is a strong correlation between firms' size and the tax deficiencies. Figure 2 displays a scatter plot and fitted values for mean audit adjustments scaled by total income for firm in each percentile group by total assets. The data show that larger firms (measured by total assets) tend to have smaller audit adjustments (as a fraction of total income). There are several potential explanations for the relationship, including higher audit rates for large firms. Whatever the cause, the link between firms' size and tax deficiencies influences our empirical approach described in the next section.

[Figure 2 about here]

Before discussing the parameterized model, it is useful to look at raw correlations. Figure 3 shows a scatter plot of mean audit adjustments (scaled by total income) and mean CPI for countries in our sample. One can clearly see a positive relationship between levels

12 These numbers reflect exclusions for missing data on any regression variables.

${ }^{13}$ Negative audit adjustments suggest that a non-trivial fraction of firms over-report their tax liability. These cases may be errors or strategic behavior to reduce the likelihood of a costly audit. We find that those with positive adjustments are slightly larger firms than average and more likely to have multinational operations and be publicly traded. Otherwise these firms appear very similar to others in the sample. 
of corruption and scaled tax deficiencies. Figure 4 cuts the raw data in a different manner. Each line shows the relationship between the level of corruption in the foreign controller's home country and the mean amount of scaled audit adjustment for firms in a particular quartile (measured by total assets. For each quartile, we see a positive relationship in the amount of evasion as the corruption level in the foreign owner's country increases. The level of evasion is highest, and the relationship between corruption and evasion strongest, in the first two quartiles. This graph shows the importance that firm size plays in determining the extent to which corruption norms influence corporate tax evasion.

The next section explores the relationship between corruption norms and tax evasion, testing whether it continues to hold after controlling for important covariates and sources of bias.

[Figure $3 \& 4$ about here]

\section{Empirical strategies and results}

\subsection{Baseline specification with constant effect}

Our empirical approach follows Fisman and Miguel (2007) and Hanlon, Mills and Slemrod (2007). We exploit the fact that firms have owners from different countries and thus have different corruption norms, but are subject to the same legal incentives in the U.S. We hypothesize that the owners of these firms may either influence the management of the firm, or manage the firm themselves, in which case the norms and customs of these owners would be likely to be manifest in the firms' behavior. In particular, firms with owners from more corrupt countries, where not following de jure rules is more acceptable, will show a higher propensity to engage in illicit activities. 
In the first and most parsimonious specification, we assume that corruption norms have a constant effect on tax evasion across firms. Our regression equation is of the following form:

$$
\begin{aligned}
\left(\frac{\text { Deficiency } \left._{\text {Revene }}\right)_{i, t} *}{}\right. & 100=\alpha_{1} \text { Corruption }_{i, t}+\beta_{1} \text { FirmCharacteristic }_{i, t} \\
& +\beta_{2} \text { CountryCharacteristic }_{i}+\beta_{2} X_{i, t}+\eta_{t}+\varepsilon_{i, t}
\end{aligned}
$$

where $i$ denotes the firm, $t$ denotes the year, Deficiency measures the change in tax liability following an audit, Revenue is total income of the firm, ${ }^{14}$ Corruption is the measure of corruption in the foreign owner's home country, the control variable vector FirmCharacteristic contains characteristics of the firm including the log of total assets, industry dummies, and indicator variables for public or multinational status. $X$ is the vector of other control variables. The parameters $\eta_{t}$ are year dummies to control for macroeconomic fluctuations and other factors that contemporaneously affect all firms.

In this type of empirical analysis, one must be concerned about three possible sources of bias: reverse causality, omitted variable bias, and selection bias. Fortunately, in model (1), reverse causality is not a problem because a firm's tax evasion in the U.S. is unlikely to change the general corruption level in its home country.

Omitted variable bias, on the other hand, may be a problem if there are some unobserved factors included in the disturbance term $\varepsilon$ that are correlated with Corruption. The fact that this study analyzes only firms that operate in the U.S. eliminates many such confounding factors related to the firm's legal and business environment, which often

\footnotetext{
14 Using total income or total assets as the measure of scale yields very similar results. In this paper, we will report specifications using total revenue as the measure of scale because reported total revenue tends to be more stable. Because total assets do not affect tax liability, the quality of these data are more suspect than income measures.
} 
challenge cross-country studies. ${ }^{15}$ Nevertheless, besides factors in the firm's environment, there may remain factors in the owner's home country that both correlate with Corruption and induce the firm to evade tax in the U.S. For example, one might argue that firms with owners from poorer countries may have higher marginal utility for income and therefore have a stronger incentive to evade tax in the U.S. Or, one could argue that firms that come from countries with fewer economic ties to the United States, or whose home countries are further from the United States, might have a stronger incentive to evade tax or have less knowledge of U.S. accounting standards (which could lead to larger measured evasion). To address these concerns, following Fisman and Miguel (2007), we control for GDP per capita and other country-level characteristics that could possibly offer such a link. For the same reason, we also control for the net income of the firm, as it may affect the owner's marginal utility of income. Further, we also include country fixed effects, which eliminate all concerns about any time-invariant factors unobservable at the country level.

Finally, because IRS audits are not randomly assigned, sample selection is a potential concern. This has been acknowledged but not addressed in the existing studies using audit data. Fortunately, the IRS data provide us with the Discriminant Information Function System (DIF) score for each firm in the sample. The IRS computes this score to predict the potential of unreported income and uses it to select firms for auditing. IRS (2011) states that "IRS personnel screen the highest-scoring returns, selecting some for audit and identifying the items on these returns that are most likely to need review." To effectively mitigate the sample selection issue, we include the firm's DIF score in all of the specifications that follow. We also control for a range of other firms' characteristics mentioned in the previous

15 It is true that the business environment may vary even within the U.S. However, this variation is much smaller than the variation across countries. In case there is selection into different states (due to legal environment or local norms regarding illegal behavior) we have estimated specification with state fixed effects and found the results consistent with those presented in this paper. 
page since IRS auditors use DIF and these characteristics of firms to determine which firms to audit. Although this might not eliminate completely eliminate sample selection as a potential selection concern, we believe this should relieve most of it and is an improvement over other approaches in the literature. ${ }^{16}$

We censor the Deficiency variable at zero, as in Hanlon, Mills, and Slemrod (2007). There exist firms who realize decreases in tax liability following an audit, but we choose to treat them as having no adjustment since they likely had a reporting error against their favor. ${ }^{17}$ Because the resulting data are censored, we use a Tobit model for all of the main specifications in this study. Alternative models including OLS and panel data methods are used as robustness checks and reported in Section 3.3.

In light of Hanlon, Mills, and Slemrod (2007) finding of a prominent relationship between firms' size and tax evasion, it is useful to see if the effect of corruption norms varies across different firms' size groups. Thus, in addition to using the full sample, we split the sample into four quartiles by firm asset size and run the analysis separately for each of these subsamples.

If corruption norms increase tax evasion, we should expect the coefficient of Corruption to be positive and significant. Table 3 shows the results of our baseline specification. Column 1 reports the results for the full sample (with 25,541 observations) while Columns 2-5 report the results for the four quartiles (around 6,385 observations each). In the full sample, the corruption measure has a positive and strongly significant effect on tax evasion. This effect is positive and significant separately for Quartile 1 and 2; negative

\footnotetext{
16 One might be concerned that the foreign investors that invest in the U.S. may be different from the typical domestic investors in that foreign country. We do not argue against this. However, our study aims to compare foreign investors in the U.S., not typical investors in different countries.

17 It is also possible that these firms overpaid in hopes of reducing the probability of incurring the costs associated with an audit. In either case, treating firms with negative adjustments to tax liability as having no change is not inappropriate nor does it lead to substantial differences in the results.
} 
but insignificant for Quartile 3, and negative and significant for Quartile 4. ${ }^{18}$ The relationship between corruption and tax evasion appears monotonic in firms' size, with the largest effect found in firms in the first quartile. The results suggest that the level of corruption in the owner's home country may have a positive effect on tax evasion for small, but not large, firms.

The coefficients of several covariates are also worth noting. Multinationals tend to evade more tax than single-national firms (Column 1). Public firms evade less than private ones. Tax evasion is most common in mining, construction, real estate, and education. It is least common in professional services, information, administrative services, and agriculture.

[Table 3 about here]

\subsection{Specification allowing the effect to vary with firms' size}

The evidence for heterogeneous effects in Table 3 requires a specification that explicitly addresses the influence of corruption norms on tax evasion that varies with firms' size. Thus, we run the following specification:

$$
\begin{aligned}
& \left(\frac{\text { Deficiency } \left._{\text {Revene }}\right)_{i, t}}{} * 100\right. \\
& =\alpha_{1} \text { Corruption }_{i, t}+\alpha_{2}{\text { Corruption } * \text { Firmsize }_{i, t}+\alpha_{3} \text { Firmsize }_{i, t}} \\
& +\beta_{1} \text { FirmCharacteristic }_{i, t} \\
& \quad+\beta_{2} \text { CountryCharacteristic }_{i}+\beta_{2} X_{i, t}+\eta_{t}+\varepsilon_{i, t}
\end{aligned}
$$

\footnotetext{
18 The negative coefficient may reflect the fact that big firms tend to be audited more frequently. As a result, if a firm that is owned by someone from a corrupt country knows they are likely to be audited, they may think that the IRS will be more diligent in looking over their return. As a result, they may be less aggressive in avoiding/evading taxes than an equivalent domestic firm would be.
} 
The main difference between (2) and (1) is the inclusion of an interaction term between Firmsize and Corruption. Firmsize is measured by total assets (instead of revenue to avoid having revenue on both sides of the equation). If the owner-country's corruption norms influence tax evasion in corporation for only smaller firms, we should expect $\alpha_{1}$ to be positive and $\alpha_{2}$ to be negative. However, if this influence takes place only among larger firms, we should expect $\alpha_{1}$ to be insignificant and $\alpha_{2}$ to be positive.

Table 4 reports the results for this specification. In Column 1, after we include Firmsize and its interaction with Corruption, the corruption measure shows a strong and positive effect on tax evasion, with an estimated coefficient of 0.756 . The interaction between the Corruption and Firmsize, on the other hand, has a strong and negative effect on tax evasion, with an estimated coefficient of -0.041 . To put these results in context, these coefficients suggest that a firm with mean assets and revenue and an owner from Afghanistan (with a CPI of 8.6 in 2010) would have an average scaled deficiency that is $\$ 61,531$ higher than a similar firm with an owner from Germany (which has a CPI of 2.1).

[Table 4 about here]

To help with the interpretation of this specification, we use the estimates in Column 1 to construct a 3-dimension graph showing the approximate predicted tax evasion as a function of owner-country's corruption norms and firms' size. Figure 5 shows that, at low levels of assets, firms with owners from more corrupt countries evade much more tax than firms whose owners come from less corrupt countries. However, this effect is only apparent among firms under a certain size. For example, a firm with $\$ 5$ million in assets with an owner from a country with an Iraqi level of corruption (8.7) on average evades more tax than a similar firm with an owner from a country with a Singaporean level of corruption (0.7) by 1.43 percentage points of their annual revenue. This amount represents a 
considerable fraction of the average tax amount that these firms pay. Holding the Iraqi corruption level constant, an increase in the level of assets reduces the propensity of firm to evade tax. For example, if the Iraqi-owned firm increases its assets from $\$ 5$ million to $\$ 102$ million, its tax evasion also falls by roughly 1.43 percentage points of its annual revenue. At the assets of $\$ 102$ million, the difference between the levels of tax evasion among the Iraqi and Singaporean firms is negligible. This interaction indicates that small size is a necessary condition for corruption norms to induce corporate tax evasion.

[Figure 5 about here]

Columns 2 through 6 add a number of variables, the omission of which might confound the effect of the CPI variable. The first of such confounding factors is the home country's GDP per capita. It might be possible that owners from poorer countries have higher marginal utility with respect to money and thus are more likely to evade tax. In Column 2, we add the log of the home country's GDP per capita and its interaction with Firmsize, exactly as we include CPI to see if GDP per capita is behind the effect of CPI. Second, it might also possible that owners from countries with greater economic ties with the U.S. tend to follow the U.S. business practices more closely. In Column 3 we add the log of the amount of bilateral trade with the United States and its interaction with Firmsize. Third, it might be that owners from countries with shorter distance to the U.S. share a greater exchange with America in various social dimensions. Thus, in Column 4 we add the log of the distance of the owner's home country from the United States. These variables are used to test whether the economic and geographic characteristics of the owner's home country, instead of its corruption level, are the true determinants of the firm's propensity to evade tax. An additional concern with the specification in Column 1 is that firms with less net income might be less likely to evade, since they have less of a tax base from which they can evade. 
On the other hand, firms with less net income might engage in more evasion in order to increase lean profit margins. If countries CPI's are systematically correlated with net income, then the estimated effect of corruption of the owner's home country may be biased. In Column 5, we add to the base specification a measure of the firm's net income and its interaction with Firmsize. Finally, in Column 6, we estimate a specification that includes all of the possibly confounding factors and their interactions with firms' size.

Across these specifications, it seems that firms from richer countries, countries with weaker trade ties with the U.S., countries with a shorter distance to the U.S. tend to evade more tax, but that these effects diminish as the size of the firm increases. In addition, firms with lower net income tend to evade more tax, but this effect also diminishes as firm size increases. However, comparing Columns (2) through (6) to Column (1), the coefficient on the corruption index remains relatively stable, varying between 0.698 and 0.963 , while the interaction between the CPI and firms' size varies only between -0.037 and -0.059 . In all specifications, both of these coefficients are highly significant. The fact that the coefficients remain steady and significant suggests that the effect of corruption is not being driven by GDP per capita, trade, or the distance from the United States. Across all of specifications, it is smaller firms from countries with higher corruption indexes that are associated with larger tax deficiencies.

Our results may still be biased, however, if there are some unobservable country level characteristics that are correlated both with the corruption measure and tax evasion. To examine whether such a concern is affecting our results, we add country fixed effects in Column (7), which eliminates all time-invariant at the country level. It is important to note, however, that in the fixed effects specification, the identification of the relationship between corruption norms and evasion is being identified through changes in firm-ownership or 
changes in the corruption levels in a particular country over time. Changes in corruption norms in a home country may manifest themselves in a number of ways. First, if these norms are related to enforcement (corruption norms and the size of the informal sector are often strongly correlated) in the home country, they may decrease evasion in the U.S. since it would be less likely for these profits to go untaxed in the home country. Second, turnover in the ownership or management of the firm may result in controllers who are more influenced by the recent cultural norms than those of the past. ${ }^{19}$ In this specification, the estimated coefficients on the CPI and its interaction with firm size are smaller, though still highly statistically significant. These results imply that when the corruption level in a country increases, firms with owners from that country tend to evade more tax in the US, though this effect diminishes with the firm's size. This is a strong piece of evidence that corruption norms have an impact on tax evasion in the United States.

\subsection{Robustness checks}

We estimated a number of additional specifications to test the robustness of these results. In this section, we report results from robustness checks that account for tax rate differentials, use an alternative corruption measure, use different methods of estimation, adjust the Winsorization levels, and use different samples of firms.

Differentials in corporate tax rates provide firms an incentive to move their tax liability to low-tax jurisdictions. For firms operating subsidiaries in high-tax countries like the U.S., lower rates overseas motivate firms to move the recognition of income offshore, either to the lower tax jurisdiction of the parent or that of another subsidiary. Such income shifting may lead to larger observed adjustments to tax liability following audit. To the

\footnotetext{
19 Countries of foreign controllers in our sample which have some of the largest changes in the Corruption Perceptions Index over the 1996-2007 period include Italy, Spain, Argentina, and Belgium, all of which seem shifts of over 2.35 points on the ten point scale in the 12 year sample period.
} 
extent that corruption norms are correlated with corporate income tax rates, not accounting for tax rate differentials is another potential source of bias. To control for this, we estimate our baseline size-interaction model with controls for tax rate differentials between the US and the foreign controller's country, as well as other characteristics of tax system in the foreign controller's country. Table 5 presents the results.

\section{[Table 5 about here]}

Column (1) takes the baseline size-interaction specification and adds the tax rate differential, calculated as the top US corporate income tax rate minus the top corporate income tax rate in the foreign controller's country. The tax differential is significant with a positive sign, indicating that a lower foreign tax rate relative to the US rate leads to additional tax evasion. Controlling for tax rate differentials strengthens the measured relationship between corruption and tax evasion. This is what one might expect a priori, as many low corruption countries in the OECD have relatively low corporate income tax rate while more corrupt countries often have relatively high corporate income tax rates. Column (2) adds the interaction of the tax rate differential with corruption norms, showing the tax rate differential to have a positive, though insignificant effect, on evasion and the interaction to have a negative and insignificant effect on evasion.

Columns (3) and (4) allow the effect of tax rate differentials to differ with other characteristics of the foreign controller's country's tax regime. Column (3) adds the interaction between tax rate differentials and a worldwide tax system. In this specification, the coefficient on the rate differential retains it positive sign, but the interaction term is negative. This suggests that rate differentials matter less in the case of the foreign controller's country having a worldwide tax regime than if a territorial system were in place. However, this relationship is less strong if the foreign controller's country has a higher level 
of corruption. Under a territorial system, the effect of evading U.S. tax may be stronger as U.S.-earned income will not be subject to a tax in the parent's home country. In addition, in a worldwide system, tax credits are often given for taxes paid in other counties, therefore reducing taxes paid in the home country and again reducing the incentive to avoid U.S. taxes. In Column (4), when the interaction of the tax rate differential and an indicator variable for tax havens is included, the tax rate differential loses its significance, and while the dummy variable for tax haven is negative, the interaction with tax haven and corruption norms is positive and significant. ${ }^{20}$ The likely reasons for the sign and significance levels of the variables are the high correlation between tax rate differentials and tax havens and the importance of other characteristics of tax havens such as lower amounts of information sharing, which may be exploited to a greater degree by those with higher corruption norms. The coefficients on Corruption Perceptions Index and its interaction with firm size remain essentially the same in all three specifications.

In Table 6, we estimate our models with an alternative corruption measure. To this point, our analysis has used a corruption measure based on the Corruption Perception Index published annually by Transparency International. To ensure that the results that we find do not depend on this particular measure, we use another measure of corruption, namely the Control of Corruption Indicator published by the World Bank as part of the Worldwide Governance Indicators Project, and report the results of the estimation using this alternative measure of corruption with all possible controls. The magnitudes of the effects are different from those reported in Table 4 because the Control of Corruption is scaled differently from the Corruption Perception Index. Using this alternative measure, corruption again has a

\footnotetext{
20 Tax havens are identified as countries with low corporate income tax rates, no requirement for a substantive local presence and no effective information exchange with other tax authorities. In our sample, this includes countries such as Panama, Switzerland, Singapore, and Ireland, among others.
} 
consistently positive effect on tax evasion, which diminishes as a firm's size increases. In addition, the estimates are strongly significant across all specifications, suggesting that the findings are not due the particular use of the Corruption Perception Index.

[Table 6 about here]

In Table 7, we try three alternative estimation methods. As noted above, our main specification is a Tobit model, which follows Hanlon, Mills and Slemrod (2007). This is due to the fact that many firms have zero audit adjustments and based on an assumption that negative tax adjustments are mainly due to unintentional mistakes of tax filers. One may argue that some positive tax adjustments are also due to unintentional mistakes. If this is the case, we may not need to censor the tax adjustment variable at zero, and OLS may be appropriate. We report the results of the OLS model in Column (1). The effects are highly significant and consistent with the Tobit model. The marginal effects from OLS are similar to the unconditional marginal effects we find using a Tobit model.

\section{[Table 7 about here]}

An alternative approach to estimation would take advantage of the fact our data consists of a panel of firms. Since there is little change in either the ownership of firms over time, we cannot employ a firm fixed effects model. ${ }^{21}$ Therefore, a remaining approach for these panel data is to run a between-effects model. The between-effects model essentially averages out observations from the same firm, thus addressing potential autocorrelation among them. We report the results of the between-effects model in Column (2) of Table 7. The between-effect estimator, like the OLS estimator, results in strongly significant estimates of the effect of corruption on tax evasion in the consistent direction with our base

\footnotetext{
${ }^{21}$ In addition, the mean number of times a firm is in the sample is only 1.7 , and thus many firms are dropped from the estimation sample when fixed effects are included. Furthermore, a firm-level fixed effect may be inappropriate if cultural norms are persistent.
} 
specification. Our final alternative estimator uses a binary dependent variable indicating whether the firm has a positive deficiency (after an audit) or not. Running a Probit model using such a dependent variable eliminates two concerns: (i) whether we should censor the data; and (2) whether the ratio of tax deficiency over revenue is a good measure of tax evasion. Results from the Probit model are available in Column (3). These results show that coefficients on the corruption level and it's interaction with firm size retain their size and strong significance in a binary model.

In Table 8, we report results from our main specification when other Winsorization levels are used. All of the analyses above used 90\% Winsorization for all monetary variables, by setting observations below the $5^{\text {th }}$ percentile to the $5^{\text {th }}$ percentile, and observations above the $95^{\text {th }}$ percentile to the $95^{\text {th }}$ percentile. This is a typical strategy to address the problem of outliers, and is necessary because the raw data from CDW includes a number of erroneous entries that have extreme values. When the data are not Winsorized, the estimates become extremely large, indicating the problem of erroneous entries that we mentioned above. Further, reducing the level of Winsorization from $90 \%$ to $98 \%$ actually enlarges both the main and interaction effects of corruption on tax evasion. Although increasing it to $80 \%$ reduces the point estimates, the effects remain strongly significant. This indicates that the main findings above are not sensitive to the choice of Winsorization level.

\section{[Table 8 about here]}

Our sample thus far includes only firms that were foreign-controlled corporations during at least one year of our sample period, and so excludes firms that are consistently owned by U.S. citizens. It is possible that the exclusion of US-owned firms in the sample could affect the results. In Column (1) of Table 9 we report the estimation on the full sample that includes both U.S. and foreign-controlled firms. Adding U.S. firms increase the 
sample size by around 11 times but maintains the main findings. The point estimates in the full sample are smaller than those of the foreign sample but they are still strongly significant. Further, our sample includes only firms incorporated in the US (Form 1120 filers) and not those incorporated overseas (Form 1120F filers). In Columns (2) and (3) in Table 9, we test whether the results differ when firms incorporated overseas are added to the sample, and the corruption measure of the country of incorporation is used instead of the country of the owner. In Column (2), we include all firms, whether they are incorporated in the U.S. or in a foreign country. In this specification, both the main effect of the CPI and the CPI interacted with firms' size switch sign compared to our main specification, and neither is significant. However, this sample is dominated by firms incorporated in the U.S. To avoid such a concentration, in Column (3), we run the main specification on the subsample of firms that are incorporated outside of the U.S. Although the point estimates are somewhat different, the pattern is the same as in our main specification. Corruption norms increase tax evasion but this effect diminishes as the firms' size increases, and both estimates are significant despite a very small sample that includes only 585 observations. Thus, the norms of the country of incorporation also appear to influence tax evasion.

[Table 9 about here]

The stable pattern of the main regression results in all of these tests suggest that corruption norms have a robust and strong effect on tax evasion, and this effect diminishes as the size of the firm increases. 


\section{Effects of enforcement}

In early 2000s, the IRS implemented two major measures against corporate tax evasion, namely the 2002 passage of the Sarbanes-Oxley Act and the tax year 2004 introduction of schedule M-3. The Sarbanes-Oxley Act increased penalties for noncompliance and requires the company's CEO to sign off on the firm's tax return, among other changes. The addition of schedule M-3 to Form 1120 requires the firm to report much more detail on book-tax differences than had been asked for previously. These new regulations have the potential to affect tax evasion through increased penalties or an increased probability of detection due to additional disclosures of tax positions.

An important question is whether these enforcement measures reduce tax evasion by firms owned by individuals from corrupt countries. To answer this question, we employ a difference-in-difference estimation strategy. Specifically, we create indicator variables for a firm being affected by each of these measures in the years in which they applied, ${ }^{22}$ along with their interaction with the CPI measure. These results are presented in Table 10.

Columns (1)-(2) include the Sarbanes-Oxley and Schedule M-3 indicators separately ${ }^{23}$, while Column (3) includes both of these measures of enforcement. In Columns (1)-(2), each of the enforcement measures enter with the expected signs - implementation of the measure leads to decreased tax deficiencies found upon audit, though the effect is smaller for firms with owners from more corrupt countries. In addition, Sarbanes-Oxley and its interaction with CPI, and the interaction of Schedule M-3 with CPI, are statistically

\footnotetext{
22 The Sarbanes-Oxley Act applied to public firms in 2002 and later, the addition of Schedule M-3 to form 1120 applied to firms with assets greater than $\$ 10$ million in 2004 and later. We also attempted to ascertain the effect of the 2006 adoption of FASB Interpretation No. 48 (FIN 48), the 2003 JGTRRA dividend tax cuts and the 2001 accounting scandals, but found no significant effects

23 Since Schedule M-3 applied only to firms with assets greater than $\$ 10$ million, in specifications that include the Schedule M-3 indicator, we also include an indicator for the firm reporting assets in excess of $\$ 10$ million. Sarbanes-Oxley Act was applied to public firms. We have already included the indicator for this characteristic throughout all specifications.
} 
significant. When both measures are entered into the regression in Column (3), the pattern of significance remains. Overall, these results seem to suggest that these two enforcement/reporting measures led to declines in tax deficiencies, though the effect was weaker among firms with owners from more corrupt countries. In addition, the direct effect of the corruption index and its interaction with firms' size are qualitatively similar to those found in Table 4. [Table 10 about here].

Another important measure of enforcement that the IRS uses to fight tax evasion is to increase the probability of audit. A recent study by Hanlon, Hoopes, and Shroff (2011) indicates that this measure has a significant effect on corporate tax evasion. From this paper's perspective, it would be intriguing to see if increased audit probability has differential effects on firms with different corruption norms. Thus, in Table 10 we add two different year-specific measures of the audit rate (by firms' size, and by firms' size and state) along with their interactions with the CPI measure. The results reported in columns (4) and (5) show that higher audit rates are again associated with lower tax deficiencies found upon audit, that this effect is attenuated for firms with owners from more corrupt countries, and that the direct effect of the corruption index and its interaction with firms' size are qualitatively similar to those found in Table 4.

Taken together, these results suggest that IRS measures are effective in reducing corporate tax evasion. However, these measures appear consistently less effective for firms with owners from more corrupt countries. In addition, the direct effect of the owner's corruption norms on tax evasion remains consistently stable after the implementation of

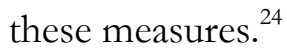

\footnotetext{
${ }^{24}$ Nonetheless, we consider this result as tentative evidence for the efficacy of enforcement measures against tax evasion by firms with corrupt norms. A rigorous analysis of the issue will be presented in DeBacker, Heim and Tran (2011).
} 


\section{Conclusion}

This paper studies the link between social norms, law enforcement and illicit corporate behavior. We find evidence that corporations with owners from more corrupt countries are more likely to evade tax in the U.S., particularly when the firm is smaller (as measured by total assets). The result extends the previously known influence of corruption norms on individual behavior (Fisman and Miguel 2007) to an important organizational behavior.

We observe that as the size of the firm increases, the influence of corruption norms diminishes. This finding appears somewhat in contrast to Joulfaian (2000), who finds that managers' preferences for individual income tax evasion influenced corporate tax evasion, but that this influence did not vary with the firm's size. However, it is important to note that the current study examines owners, while Joulfaian (2000) examines managers, suggesting that the influence of owners decreases with a firm's size, while the influence of managers does not. Taken together, these results imply that the stronger separation of ownership and control in larger firms may attenuate the influence of corruption norms of owners. Putting the different pieces of evidence together helps us to better understand the corporate governance 'black-box' and the propensity of corporations to engage in illicit activities.

Contrary to Fisman and Miguel (2007), who show that diplomats from corrupt countries cut their illegal parking immediately when the law enforcement increased, we find that corruption norms pose a challenge in combatting corporate tax evasion: firms with higher corruption norm are less likely to respond to increased enforcement activities. This difference suggests that individuals and organizations may react to enforcement quite distinctively. While there might be various reasons for this difference, we can be certain that 
cultural factors should be taken seriously in order to design effective law enforcement programs.

Our paper has certain limitations. Although the operation of foreign owned firms in the U.S. provides a unique natural experiment, a number of issues may bias our estimates. First, there might be omitted variables at the country level that may drive the results. To address this concern, as in Fisman and Miguel (2007), we controlled for many country specific variables (including country fixed effects) that may possibly correlate with both corruption and U.S. tax evasion, but other unobserved time-variant factors may remain that could bias our results. Second, we cannot fully utilize our panel and include firm-specific fixed effects, as the firm's ownership variables change very little during the period of study. Furthermore, we only observe a firm's tax deficiency when it is audited, which, for most firms, is not a frequent event. Thus our ability to identify the role of corruption through within firm variation is very limited. Lastly, the non-random selection of our sample may lead to selectivity bias. We use different characteristics of the firms, particularly the IRS's Discriminant Function System score to correct for such possible bias. We believe that this should eliminate most of the bias, but it may not account completely for selection.

Nevertheless, the fact that the relationship between corruption norms and tax evasion remain significant and consistent in all specifications indicates a robust linkage between norms and corporate illicit activities. Culture appears to play an important role in tax evasion, and the current enforcement policies seem less effective in dealing with it. Our findings call for the consideration of cultural factors in designing corporate governance and law enforcement. In this globalized world, what happens far away may have implications for us at home. 


\section{References}

Andreoni, James, Brian Erard, and Jonathan Feinstein. (1998). "Tax Compliance.” Journal of Economic Literature. Vol. 36, No. 2, p. 818-860.

Allingham, Maurice. G. and Agnar Sandmo (1972). "Income Tax Evasion: A Theoretical Analysis.” Journal of Public Economics. Vol. 1, p. 323-338.

Barth, James R., Chen Lin, Ping Lin, Frank M. Song, (2009). "Corruption in bank lending to firms: Cross-country micro evidence on the beneficial role of competition and information sharing", Journal of Financial Economics, Vol. 91, No 3, p. 361-388.

Becker, Gary S. (1968). “Crime and Punishment: An Economic Approach.” Journal of Political Economy. Vol 76, No. 2, p. 169-217.

Borjas, George J. (2000). "The Economic Progress of Immigrants." in Issues in the Economics of Immigration, ed. by George J. Borjas. Chicago: University of Chicago Press.

CEPII Research Center, (2006), The dist_cepii file, Retrieved in July 2011, from www.cepii.fr/anglaisgraph/bdd/distances.htm

Crocker, Keith J. and Joel Slemrod. (2005). "Corporate Tax Evasion with Agency Costs." Journal of Public Economics. Vol. 89, p. 1593-1610

DeBacker, Jason, Bradley T. Heim and Anh Tran (2011). "Law Enforcement and Corporate Illegal Activity: An Analysis of Tax Evasion in the U.S.” Working paper.

Desai, Mihir A. and Dhammika Dharmapala. (2006). "Corporate Tax Avoidance and HighPowered Incentives.” Journal of Financial Economics. Vol. 79, No. 2, p. 145-179.

Djankov, Simeon, Rafael La Porta, Florencio Lopez-De-Silanes, Andrei Shleifer. (2002). “The Regulation of Entry." Quarterly Journal of Economics, February 2002, Vol. 117, No. 1, Pages 1-37.

Fernandez, Raquel and Alessandra Fogli. (2006). "Fertility: The Role of Culture and Family Experience.” Journal of the European Economic Association. Vol. 4 (April-May), p. 552-561.

Fisman Raymond. (2001). "Estimating the Value of Political Connections." The American Economic Review, Vol. 91, No. 4, p. 1095-1102.

Fisman, Raymond and Edward Miguel. (2007). "Corruption, Norms, and Legal Enforcement: Evidence from Diplomatic Parking Tickets.” Journal of Political Economy. Vol. 155, No. 6, p. 1020-1048.

Frey, Bruno S. (1997). Not Just for The Money. An Economic Theory of Personal Motivation. Edward Elgar, Cheltenham. UK. 
Hanlon, Michelle, Lillian Mills and Joel Slemrod. (2007). "An Empirical Examination of Corporate Tax Noncompliance." in Taxing Corporate Income in the 21st Century, eds. Alan J. Auerbach, James R. Hines and Joel Slemrod. New York: Cambridge University Press.

Hanousek, Jan and Filip Palda. (2004). "Quality of Government Services and the Civic Duty to Pay Taxes in the Czech and Slovak Republics, and other Transition Countries." Kyklos. Vol. 57, No. 2, p. 237-252.

Ichino, Andrea, and Giovanni Maggi. (2000). "Work Environment and Individual Background: Explaining Regional Shirking Differentials in a Large Italian Firm.” Quarterly Journal of Economics. Vol. 115, p. 1057-90.

Joulfaian, David. (2000). "Corporate Income Tax Evasion and Managerial Preferences." The Review of Economics and Statistics. Vol. 82, No. 4, p. 698-701.

Levi, Margaret. (1998). "A State of Trust.” in Trust and Governance, ed by Valerie Braithwaite and Margaret Levi. p. 77-101. New York: Russell Sage Foundation.

Mathiason, Nick. (2008). “Tax evasion robs developing countries of $\$ 900 \mathrm{bn}$ a year." The Observer. 30th November 2008

Sandmo, Agnar. (2005). “The Theory of Tax Evasion: A Retrospective Review.” National Tax Journal. Vol. 58, p. 643-664.

Slemrod, Joel. (2003). "Trust in Public Finance." in Public Finance and Public Policy in the New Century, eds. Sijbren Cnossen and H-W Sinn. p. 49-88. Cambridge, MA: MIT Press.

Slemrod, Joel. (2004). “The Economics of Corporate Tax Selfishness.” NBER Working Paper 10858.

Slemrod, Joel. (2007). "Cheating Ourselves: The Economics of Tax Evasion.” Journal of Economic Perspectives. Vol 21, No. 1, p. 25-48.

Torgler, Benno. (2003). “Tax Morale, Rule-Governed Behaviour, and Trust.” Constitutional Political Economy, Vol. 14, No. 2, p. 119-104.

United States Census Bureau, (2010), "U.S. Foreign Economic and Military Aid by Major Recipient Country: 2001 to 2008," United States Census Bureau, Retrieved in July 2011, from http://www.census.gov/compendia/statab/cats/foreign_commerce_aid/foreign_aid.html

United States Census Bureau, (2011), “U.S. Trade in Goods by Country,” United States Census Bureau, Retrieved in July 2011, from http://www.census.gov/foreign-trade/balance/,

United State Department of the Treasury, Internal Revenue Service, (2006) "Updated Estimates of the TY2001 Individual Income Tax Underreporting Gap. Overview" 
United States Government Accountability Office. (2008) “Comparison of the Reported Tax Liabilities of Foreign- and U.S.-Controlled Corporations, 1998-2005" 
Table 1. Summary Statistics

\begin{tabular}{|c|c|c|c|}
\hline & $\overline{\mathrm{ALL}}$ & $\overline{\mathrm{OECD}}$ & Non-OECD \\
\hline Audit Adjustment & 88.776 & 91.720 & 61.189 \\
\hline Audit Adjustment/Total Income * 100 & 0.671 & 0.631 & 1.048 \\
\hline Corruption Index, Country of Owner & 2.495 & 2.293 & 4.385 \\
\hline Log of Total Income & 16.848 & 16.974 & 15.674 \\
\hline Log of Net Income & 14.982 & 15.115 & 13.716 \\
\hline Log of Total Assets & 17.758 & 17.896 & 16.467 \\
\hline Public & 0.121 & 0.124 & 0.095 \\
\hline Multinational & 0.284 & 0.294 & 0.191 \\
\hline Discriminant Function Score & 65.854 & 66.186 & 62.744 \\
\hline Log of GDP per Capita (PPP) & 10.292 & 10.348 & 9.627 \\
\hline Log of Bilateral Trade & 9.097 & 9.226 & 7.436 \\
\hline Log of Distance (Population Weighted) & 8.547 & 8.529 & 8.762 \\
\hline \multicolumn{4}{|l|}{ Industry: } \\
\hline Agriculture & 0.006 & 0.006 & 0.005 \\
\hline Mining & 0.013 & 0.013 & 0.011 \\
\hline Utilities & 0.004 & 0.004 & 0.000 \\
\hline Construction & 0.012 & 0.013 & 0.010 \\
\hline Manufacturing & 0.242 & 0.249 & 0.171 \\
\hline Wholesale & 0.215 & 0.200 & 0.357 \\
\hline Retail & 0.030 & 0.030 & 0.037 \\
\hline Transport & 0.025 & 0.024 & 0.031 \\
\hline Information & 0.029 & 0.029 & 0.024 \\
\hline Finance & 0.205 & 0.214 & 0.115 \\
\hline Real Estate & 0.035 & 0.032 & 0.054 \\
\hline Professional & 0.080 & 0.079 & 0.087 \\
\hline Administrative & 0.011 & 0.010 & 0.011 \\
\hline Education & 0.003 & 0.003 & 0.002 \\
\hline Health & 0.005 & 0.005 & 0.006 \\
\hline Entertainment & 0.008 & 0.008 & 0.003 \\
\hline Hospitality & 0.009 & 0.009 & 0.015 \\
\hline Other Services & 0.007 & 0.007 & 0.010 \\
\hline Unclassified & 0.064 & 0.065 & 0.053 \\
\hline Number of Observations & 25,541 & 23,080 & 2,461 \\
\hline
\end{tabular}

Note: This table reports the means of all variables used in this research. Data from 1996-2007 Audit Information Management System merged with corporate tax returns. This dataset include 25,541 audits of foreign-controlled corporations. All dollar values are in constant 2009 dollars. Audit Adjustments are in 1000s of dollars. To deal with outliers, all monetary variables have been $90 \%$ Winsorized. Corruption Index is the Corruptions Perception Index in the reversed scale, published annually by Transparency International. 
Table 2. Audit Adjustment Sample Statistics

\begin{tabular}{lllcc}
\hline \hline & $\underline{\mathrm{N}}$ & $\underline{\text { Mean }}$ & $\underline{\text { Std Dev }}$ & \% Of Taxes Owed \\
\hline All & 25,541 & 79.99 & 234.52 & $12.46 \%$ \\
Audit Adjustment $<0$ & 4,200 & -53.37 & 59.35 & $-2.68 \%$ \\
Audit Adjustment $>0$ & 10,897 & 208.29 & 313.39 & $27.22 \%$ \\
Audit Adjustment $=0$ & 10,444 & 0.00 & 0.00 & $0.00 \%$ \\
\hline \hline Note: Data from 1996-2007 Audit Information Management System merged with corporate tax returns. All \\
dollar values are in 1000s of 2009 \$. To deal with outliers, audit adjustments have been 90\% Winsorized.
\end{tabular}


Table 3. Estimation of Relationship Between Corruption Index and Audit Adjustment

\begin{tabular}{|c|c|c|c|c|c|}
\hline & $\begin{array}{c}\text { All Firms } \\
(1) \\
\end{array}$ & $\begin{array}{c}\text { Quartile } 1 \\
(2) \\
\end{array}$ & $\begin{array}{c}\text { Quartile } 2 \\
\text { (3) }\end{array}$ & $\begin{array}{c}\text { Quartile } 3 \\
\text { (4) } \\
\end{array}$ & $\begin{array}{c}\text { Quartile } 4 \\
(5)\end{array}$ \\
\hline Corruption Index (CPI) & $\begin{array}{l}0.093 * * * \\
(0.021)\end{array}$ & $\begin{array}{l}0.189 * * * \\
(0.041)\end{array}$ & $\begin{array}{l}0.119 * * * \\
(0.037)\end{array}$ & $\begin{array}{l}0.007 \\
(0.041)\end{array}$ & $\begin{array}{l}-0.108^{* *} \\
(0.043)\end{array}$ \\
\hline $\ln$ (Total Assets) & $\begin{array}{l}-0.086^{* * *} \\
(0.014)\end{array}$ & $\begin{array}{l}-0.196 * * * \\
(0.045)\end{array}$ & $\begin{array}{l}-0.224^{* *} \\
(0.100)\end{array}$ & $\begin{array}{l}-0.056 \\
(0.072)\end{array}$ & $\begin{array}{l}0.294^{* * *} \\
(0.087)\end{array}$ \\
\hline DIF Score & $\begin{array}{c}-0.000^{*} \\
(0.000)\end{array}$ & $\begin{array}{l}0.001 * \\
(0.000)\end{array}$ & $\begin{array}{l}-0.000 \\
(0.000)\end{array}$ & $\begin{array}{l}-0.001 * * \\
(0.000)\end{array}$ & $\begin{array}{c}-0.000 \\
(0.000)\end{array}$ \\
\hline Public & $\begin{array}{l}-0.187^{* *} \\
(0.087)\end{array}$ & $\begin{array}{l}-3.420 \\
(2.420)\end{array}$ & $\begin{array}{l}-0.347 \\
(0.370)\end{array}$ & $\begin{array}{l}-0.298^{* *} \\
(0.136)\end{array}$ & $\begin{array}{l}-0.036 \\
(0.104)\end{array}$ \\
\hline Multinational & $\begin{array}{l}0.203^{* * *} \\
(0.062)\end{array}$ & $\begin{array}{l}-0.177 \\
(0.436)\end{array}$ & $\begin{array}{l}0.222^{*} \\
(0.129)\end{array}$ & $\begin{array}{l}0.068 \\
(0.094)\end{array}$ & $\begin{array}{l}0.117 \\
(0.085)\end{array}$ \\
\hline Foreign Controlled Corp. & $\begin{array}{l}-0.311^{* * *} \\
(0.078)\end{array}$ & $\begin{array}{l}-1.921 * * * \\
(0.273)\end{array}$ & $\begin{array}{l}-0.123 \\
(0.145)\end{array}$ & $\begin{array}{l}0.078 \\
(0.115)\end{array}$ & $\begin{array}{l}0.161 \\
(0.103)\end{array}$ \\
\hline Agriculture & $\begin{array}{l}-0.494 \\
(0.364)\end{array}$ & $\begin{array}{l}-0.916 \\
(0.842)\end{array}$ & $\begin{array}{l}-0.853 \\
(0.633)\end{array}$ & $\begin{array}{l}-0.495 \\
(0.583)\end{array}$ & $\begin{array}{l}0.738 \\
(0.501)\end{array}$ \\
\hline Mining & $\begin{array}{l}1.009^{* * *} \\
(0.234)\end{array}$ & $\begin{array}{l}-0.085 \\
(0.705)\end{array}$ & $\begin{array}{l}1.565^{* * *} \\
(0.499)\end{array}$ & $\begin{array}{l}-0.818^{* *} \\
(0.343)\end{array}$ & $\begin{array}{l}1.600^{* * *} \\
(0.334)\end{array}$ \\
\hline Utilities & $\begin{array}{l}0.259 \\
(0.362)\end{array}$ & $\begin{array}{l}-2.719 * \\
(1.605)\end{array}$ & $\begin{array}{l}0.001 \\
(0.731)\end{array}$ & $\begin{array}{l}0.714 \\
(1.233)\end{array}$ & $\begin{array}{l}0.209 \\
(0.340)\end{array}$ \\
\hline Construction & $\begin{array}{l}1.330^{* * *} \\
(0.299)\end{array}$ & $\begin{array}{l}1.498^{* * *} \\
(0.571)\end{array}$ & $\begin{array}{l}0.233 \\
(0.512)\end{array}$ & $\begin{array}{l}1.142^{* *} \\
(0.553)\end{array}$ & $\begin{array}{l}2.665^{* * *} \\
(0.846)\end{array}$ \\
\hline Wholesale & $\begin{array}{l}-0.052 \\
(0.072)\end{array}$ & $\begin{array}{l}0.051 \\
(0.240)\end{array}$ & $\begin{array}{l}-0.048 \\
(0.109)\end{array}$ & $\begin{array}{l}-0.047 \\
(0.114)\end{array}$ & $\begin{array}{l}-0.365^{* *} \\
(0.144)\end{array}$ \\
\hline Retail & $\begin{array}{l}-0.437 * * * \\
(0.153)\end{array}$ & $\begin{array}{l}-0.758^{*} \\
(0.442)\end{array}$ & $\begin{array}{l}-0.281 \\
(0.257)\end{array}$ & $\begin{array}{l}-0.684^{* *} \\
(0.271)\end{array}$ & $\begin{array}{l}-0.499 * * * \\
(0.168)\end{array}$ \\
\hline Transportation & $\begin{array}{l}0.176 \\
(0.177)\end{array}$ & $\begin{array}{l}0.550 \\
(0.399)\end{array}$ & $\begin{array}{l}0.335 \\
(0.340)\end{array}$ & $\begin{array}{l}-0.611 * \\
(0.330)\end{array}$ & $\begin{array}{l}-0.315 \\
(0.223)\end{array}$ \\
\hline Information & $\begin{array}{l}-0.359 * * \\
(0.151)\end{array}$ & $\begin{array}{l}-1.238^{* *} \\
(0.484)\end{array}$ & $\begin{array}{l}-0.298 \\
(0.288)\end{array}$ & $\begin{array}{l}-0.433 \\
(0.264)\end{array}$ & $\begin{array}{l}0.261 \\
(0.221)\end{array}$ \\
\hline Finance & $\begin{array}{l}0.149 * * \\
(0.073)\end{array}$ & $\begin{array}{l}0.284 \\
(0.428)\end{array}$ & $\begin{array}{l}-0.269 \\
(0.171)\end{array}$ & $\begin{array}{l}-0.020 \\
(0.121)\end{array}$ & $\begin{array}{l}0.063 \\
(0.093)\end{array}$ \\
\hline Real Estate & $\begin{array}{l}0.863^{* * *} \\
(0.193)\end{array}$ & $\begin{array}{l}2.245^{* * *} \\
(0.444)\end{array}$ & $\begin{array}{l}-0.239 \\
(0.281)\end{array}$ & $\begin{array}{l}0.439 \\
(0.379)\end{array}$ & $\begin{array}{l}0.239 \\
(0.398)\end{array}$ \\
\hline Professional Services & $\begin{array}{l}-0.224 * * \\
(0.113)\end{array}$ & $\begin{array}{l}-0.692^{* *} \\
(0.300)\end{array}$ & $\begin{array}{l}-0.456^{* *} \\
(0.189)\end{array}$ & $\begin{array}{l}0.280 \\
(0.217)\end{array}$ & $\begin{array}{l}0.189 \\
(0.249)\end{array}$ \\
\hline Administrative Services & $\begin{array}{l}-0.265 \\
(0.273)\end{array}$ & $\begin{array}{l}-1.366^{* *} \\
(0.690)\end{array}$ & $\begin{array}{l}-0.077 \\
(0.367)\end{array}$ & $\begin{array}{l}-0.606 \\
(0.483)\end{array}$ & $\begin{array}{l}0.552 \\
(0.569)\end{array}$ \\
\hline Education & $\begin{array}{l}0.865^{*} \\
(0.491)\end{array}$ & $\begin{array}{l}0.674 \\
(0.857)\end{array}$ & $\begin{array}{l}2.267 * * \\
(0.930)\end{array}$ & $\begin{array}{l}-0.695 \\
(0.747)\end{array}$ & $\begin{array}{l}0 \\
0\end{array}$ \\
\hline Health Care & $\begin{array}{l}0.386 \\
(0.330)\end{array}$ & $\begin{array}{l}0.586 \\
(0.882)\end{array}$ & $\begin{array}{l}-0.157 \\
(0.500)\end{array}$ & $\begin{array}{l}1.017 \\
(0.775)\end{array}$ & $\begin{array}{l}-0.123 \\
(0.388)\end{array}$ \\
\hline Entertainment & $\begin{array}{l}0.388 \\
(0.349)\end{array}$ & $\begin{array}{l}-0.330 \\
(0.744)\end{array}$ & $\begin{array}{l}1.001 \\
(0.621)\end{array}$ & $\begin{array}{l}0.505 \\
(0.510)\end{array}$ & $\begin{array}{l}0.035 \\
(0.468)\end{array}$ \\
\hline
\end{tabular}


Table 3 (cont.) Estimation of Relationship Between Corruption Index and Audit Adjustment

\begin{tabular}{|c|c|c|c|c|c|}
\hline & $\begin{array}{c}\text { All Firms } \\
(1)\end{array}$ & $\begin{array}{c}\text { Quartile } 1 \\
(2) \\
\end{array}$ & $\begin{array}{c}\text { Quartile } 2 \\
\text { (3) }\end{array}$ & $\begin{array}{c}\text { Quartile } 3 \\
\text { (4) } \\
\end{array}$ & $\begin{array}{c}\text { Quartile } 4 \\
(5)\end{array}$ \\
\hline Hospitality & $\begin{array}{l}0.142 \\
(0.296)\end{array}$ & $\begin{array}{l}0.355 \\
(0.590)\end{array}$ & $\begin{array}{l}-0.312 \\
(0.464)\end{array}$ & $\begin{array}{l}-0.460 \\
(0.449)\end{array}$ & $\begin{array}{l}0.507 \\
(0.708)\end{array}$ \\
\hline Other Services & $\begin{array}{l}-0.633^{* *} \\
(0.287)\end{array}$ & $\begin{array}{l}-1.440^{* *} \\
(0.681)\end{array}$ & $\begin{array}{l}0.213 \\
(0.470)\end{array}$ & $\begin{array}{l}-0.558 \\
(0.418)\end{array}$ & $\begin{array}{l}-2.558^{* * *} \\
(0.901)\end{array}$ \\
\hline Misc-Unclassified & $\begin{array}{l}0.428^{* * *} \\
(0.123)\end{array}$ & $\begin{array}{l}1.434^{* * *} \\
(0.338)\end{array}$ & $\begin{array}{l}-0.084 \\
(0.269)\end{array}$ & $\begin{array}{l}-0.325 \\
(0.223)\end{array}$ & $\begin{array}{l}0.082 \\
(0.165)\end{array}$ \\
\hline 1996 & $\begin{array}{l}0.336^{* * *} \\
(0.112)\end{array}$ & $\begin{array}{l}0.543 \\
(0.347)\end{array}$ & $\begin{array}{l}-0.036 \\
(0.199)\end{array}$ & $\begin{array}{l}0.566^{* * *} \\
(0.171)\end{array}$ & $\begin{array}{l}0.046 \\
(0.191)\end{array}$ \\
\hline 1997 & $\begin{array}{l}0.047 \\
(0.122)\end{array}$ & $\begin{array}{l}-0.154 \\
(0.376)\end{array}$ & $\begin{array}{l}-0.137 \\
(0.229)\end{array}$ & $\begin{array}{l}0.322 \\
(0.197)\end{array}$ & $\begin{array}{l}-0.043 \\
(0.209)\end{array}$ \\
\hline 1998 & $\begin{array}{l}0.012 \\
(0.121)\end{array}$ & $\begin{array}{l}-0.263 \\
(0.372)\end{array}$ & $\begin{array}{l}-0.358 \\
(0.235)\end{array}$ & $\begin{array}{l}0.204 \\
(0.187)\end{array}$ & $\begin{array}{l}-0.013 \\
(0.214)\end{array}$ \\
\hline 1999 & $\begin{array}{l}0.070 \\
(0.129)\end{array}$ & $\begin{array}{l}0.052 \\
(0.387)\end{array}$ & $\begin{array}{l}-0.283 \\
(0.254)\end{array}$ & $\begin{array}{l}-0.064 \\
(0.212)\end{array}$ & $\begin{array}{l}-0.075 \\
(0.231)\end{array}$ \\
\hline 2000 & $\begin{array}{l}0.112 \\
(0.149)\end{array}$ & $\begin{array}{l}0.033 \\
(0.456)\end{array}$ & $\begin{array}{l}-0.569 * \\
(0.293)\end{array}$ & $\begin{array}{l}0.055 \\
(0.262)\end{array}$ & $\begin{array}{l}-0.059 \\
(0.274)\end{array}$ \\
\hline 2001 & $\begin{array}{l}0.122 \\
(0.156)\end{array}$ & $\begin{array}{l}1.029^{*} \\
(0.572)\end{array}$ & $\begin{array}{l}-0.237 \\
(0.291)\end{array}$ & $\begin{array}{l}0.214 \\
(0.273)\end{array}$ & $\begin{array}{l}-0.357 \\
(0.254)\end{array}$ \\
\hline 2002 & $\begin{array}{l}-0.055 \\
(0.135)\end{array}$ & $\begin{array}{l}-0.601 \\
(0.472)\end{array}$ & $\begin{array}{l}-0.112 \\
(0.270)\end{array}$ & $\begin{array}{l}0.261 \\
(0.234)\end{array}$ & $\begin{array}{l}-0.303 \\
(0.218)\end{array}$ \\
\hline 2003 & $\begin{array}{l}0.016 \\
(0.126)\end{array}$ & $\begin{array}{l}-0.017 \\
(0.465)\end{array}$ & $\begin{array}{l}-0.049 \\
(0.213)\end{array}$ & $\begin{array}{l}-0.047 \\
(0.192)\end{array}$ & $\begin{array}{l}-0.167 \\
(0.212)\end{array}$ \\
\hline 2004 & $\begin{array}{l}0.095 \\
(0.119)\end{array}$ & $\begin{array}{l}0.501 \\
(0.413)\end{array}$ & $\begin{array}{l}-0.008 \\
(0.191)\end{array}$ & $\begin{array}{l}-0.186 \\
(0.175)\end{array}$ & $\begin{array}{l}-0.017 \\
(0.203)\end{array}$ \\
\hline 2005 & $\begin{array}{l}0.122 \\
(0.120)\end{array}$ & $\begin{array}{l}0.145 \\
(0.397)\end{array}$ & $\begin{array}{l}0.135 \\
(0.196)\end{array}$ & $\begin{array}{l}0.059 \\
(0.193)\end{array}$ & $\begin{array}{l}-0.213 \\
(0.193)\end{array}$ \\
\hline 2006 & $\begin{array}{l}0.267^{* *} \\
(0.119)\end{array}$ & $\begin{array}{l}1.126^{* * *} \\
(0.393)\end{array}$ & $\begin{array}{l}0.005 \\
(0.189)\end{array}$ & $\begin{array}{l}0.084 \\
(0.186)\end{array}$ & $\begin{array}{l}-0.041 \\
(0.197)\end{array}$ \\
\hline Constant & $\begin{array}{l}0.116 \\
(0.282)\end{array}$ & $\begin{array}{l}1.622 * * \\
(0.778)\end{array}$ & $\begin{array}{l}2.682 \\
(1.719)\end{array}$ & $\begin{array}{l}-0.309 \\
(1.360)\end{array}$ & $\begin{array}{l}-6.733^{* * *} \\
(1.763)\end{array}$ \\
\hline Sigma & $\begin{array}{l}3.526^{* * *} \\
(0.050)\end{array}$ & $\begin{array}{l}5.210^{* * *} \\
(0.101)\end{array}$ & $\begin{array}{l}3.112^{* * *} \\
(0.098)\end{array}$ & $\begin{array}{l}2.937^{* * *} \\
(0.112)\end{array}$ & $\begin{array}{l}2.642^{* * *} \\
(0.090)\end{array}$ \\
\hline $\mathrm{N}$ & 25541 & 6386 & 6385 & 6385 & 6385 \\
\hline
\end{tabular}

Notes: This table reports the regression results of tax adjustment after the audit (as percent of the firm's revenue) on the corruption index of the owner's home country. The results for the full sample and each quartile of firm size are reported. Data from 1996-2007 Audit Information Management System merged with corporate tax returns. All dollar values are in constant 2009 \$. To deal with outliers, monetary variables have been $90 \%$ Winsorized. All specifications include year dummies and a constant. Robust standard errors are in parentheses. ${ }^{*} \mathrm{p}<0.10,{ }^{* *}$ $\mathrm{p}<0.05, * * * \mathrm{p}<.01$ 
Table 4. Estimation of Relationship Between Corruption Index and Audit Adjustment Allowing Effect to Differ by Firm Size, With Robustness Checks

\begin{tabular}{|c|c|c|c|c|c|c|c|}
\hline & $\begin{array}{c}\text { Base } \\
(1) \\
\end{array}$ & $\begin{array}{l}\text { With } \\
\text { GDP } \\
(2) \\
\end{array}$ & $\begin{array}{c}\text { With } \\
\text { Trade } \\
(3) \\
\end{array}$ & $\begin{array}{l}\text { With } \\
\text { Dist } \\
(4) \\
\end{array}$ & $\begin{array}{c}\text { With } \\
\text { Income } \\
(5)\end{array}$ & $\begin{array}{l}\text { With } \\
\text { All } \\
(6) \\
\end{array}$ & $\begin{array}{c}\text { Country } \\
\text { Fixed Effect } \\
\text { and All } \\
(7) \\
\end{array}$ \\
\hline Corruption Index (CPI) & $\begin{array}{l}0.756^{* * *} \\
(0.125)\end{array}$ & $\begin{array}{l}0.963 * * * \\
(0.183)\end{array}$ & $\begin{array}{l}0.778^{* * *} \\
(0.135)\end{array}$ & $\begin{array}{l}0.808^{* * *} \\
(0.127)\end{array}$ & $\begin{array}{l}0.698^{* * *} \\
(0.134)\end{array}$ & $\begin{array}{l}0.783^{* * *} \\
(0.208)\end{array}$ & $\begin{array}{l}0.562^{* *} \\
(0.238)\end{array}$ \\
\hline CPI* $\ln$ (Total Assets) & $\begin{array}{l}-0.041^{* * *} \\
(0.007)\end{array}$ & $\begin{array}{l}-0.059^{* * *} \\
(0.010)\end{array}$ & $\begin{array}{l}-0.042^{* * *} \\
(0.008)\end{array}$ & $\begin{array}{l}-0.042^{* * *} \\
(0.007)\end{array}$ & $\begin{array}{l}-0.037^{* * *} \\
(0.008)\end{array}$ & $\begin{array}{l}-0.044 * * * \\
(0.012)\end{array}$ & $\begin{array}{l}-0.032^{* * *} \\
(0.012)\end{array}$ \\
\hline $\ln ($ Total Assets) & $\begin{array}{l}0.022 \\
(0.023)\end{array}$ & $\begin{array}{l}1.269 * * * \\
(0.391)\end{array}$ & $\begin{array}{l}-0.075^{* *} \\
(0.036)\end{array}$ & $\begin{array}{l}-0.557 * * * \\
(0.144)\end{array}$ & $\begin{array}{l}-0.389 * * * \\
(0.077)\end{array}$ & $\begin{array}{l}-0.180 \\
(0.490)\end{array}$ & $\begin{array}{l}-0.159 \\
(0.529)\end{array}$ \\
\hline DIF Score & $\begin{array}{l}-0.000^{*} \\
(0.000)\end{array}$ & $\begin{array}{l}-0.000 * \\
(0.000)\end{array}$ & $\begin{array}{l}-0.000^{* *} \\
(0.000)\end{array}$ & $\begin{array}{l}-0.000^{*} \\
(0.000)\end{array}$ & $\begin{array}{l}-0.000 \\
(0.000)\end{array}$ & $\begin{array}{l}-0.000^{*} \\
(0.000)\end{array}$ & $\begin{array}{l}-0.000 * \\
(0.000)\end{array}$ \\
\hline Public & $\begin{array}{l}-0.196 * * \\
(0.087)\end{array}$ & $\begin{array}{l}-0.176^{* *} \\
(0.087)\end{array}$ & $\begin{array}{l}-0.047 \\
(0.090)\end{array}$ & $\begin{array}{l}-0.122 \\
(0.088)\end{array}$ & $\begin{array}{l}-0.249 * * * \\
(0.087)\end{array}$ & $\begin{array}{l}-0.109 \\
(0.089)\end{array}$ & $\begin{array}{l}-0.125 \\
(0.088)\end{array}$ \\
\hline Multinational & $\begin{array}{l}0.189 * * * \\
(0.062)\end{array}$ & $\begin{array}{l}0.199 * * * \\
(0.062)\end{array}$ & $\begin{array}{l}0.204^{* * *} \\
(0.062)\end{array}$ & $\begin{array}{l}0.177 * * * \\
(0.062)\end{array}$ & $\begin{array}{l}0.036 \\
(0.062)\end{array}$ & $\begin{array}{l}0.041 \\
(0.062)\end{array}$ & $\begin{array}{l}0.029 \\
(0.061)\end{array}$ \\
\hline Foreign Controlled Corp. & $\begin{array}{l}-0.335^{* * *} \\
(0.079)\end{array}$ & $\begin{array}{l}-0.592 * * * \\
(0.091)\end{array}$ & $\begin{array}{l}-0.542^{*} \\
(0.291)\end{array}$ & $\begin{array}{l}-0.072 \\
(0.117)\end{array}$ & $\begin{array}{l}-0.186^{* *} \\
(0.077)\end{array}$ & $\begin{array}{l}0.748^{*} \\
(0.387)\end{array}$ & $\begin{array}{l}-30.214^{* * *} \\
(11.205)\end{array}$ \\
\hline $\ln ($ GDP Per Capita) & & $\begin{array}{l}1.393^{* *} \\
(0.624)\end{array}$ & & & & $\begin{array}{l}0.659 \\
(0.738)\end{array}$ & $\begin{array}{l}5.024 * * * \\
(1.241)\end{array}$ \\
\hline $\ln (\text { GDP PC })^{*} \ln ($ Total Assets $)$ & & $\begin{array}{l}-0.117^{* * *} \\
(0.036)\end{array}$ & & & & $\begin{array}{l}-0.057 \\
(0.043)\end{array}$ & $\begin{array}{l}-0.036 \\
(0.049)\end{array}$ \\
\hline $\ln ($ Trade $)$ & & & $\begin{array}{l}-0.172 * * * \\
(0.055)\end{array}$ & & & $\begin{array}{l}-0.177 * * * \\
(0.068)\end{array}$ & $\begin{array}{l}-0.322 \\
(0.274)\end{array}$ \\
\hline $\ln ($ Trade $) * \ln ($ Total Assets $)$ & & & $\begin{array}{l}0.010^{* * *} \\
(0.003)\end{array}$ & & & $\begin{array}{l}0.006^{*} \\
(0.003)\end{array}$ & $\begin{array}{l}0.011 \text { *** } \\
(0.003)\end{array}$ \\
\hline $\ln ($ Distance $)$ & & & & $\begin{array}{l}-1.493^{* * *} \\
(0.301)\end{array}$ & & $\begin{array}{l}-1.019 \text { *** } \\
(0.360)\end{array}$ & \\
\hline $\ln ($ Distance $) * \ln ($ Total Assets $)$ & & & & $\begin{array}{l}0.070^{* * *} \\
(0.017)\end{array}$ & & $\begin{array}{l}0.039 * \\
(0.020)\end{array}$ & \\
\hline $\ln ($ Net Income $)$ & & & & & $\begin{array}{l}-0.635^{* * *} \\
(0.084)\end{array}$ & $\begin{array}{l}-0.643^{* * *} \\
(0.088)\end{array}$ & \\
\hline $\ln ($ Net Income $) * \ln ($ Total Asset & & & & & $\begin{array}{l}0.034 * * * \\
(0.005)\end{array}$ & $\begin{array}{l}0.034 * * * \\
(0.005)\end{array}$ & \\
\hline Industry Dummies & Yes & Yes & Yes & Yes & Yes & Yes & Yes \\
\hline $\begin{array}{l}\text { Year Dummies } \\
\text { Country Dummies }\end{array}$ & Yes & Yes & Yes & Yes & Yes & Yes & $\begin{array}{l}\text { Yes } \\
\text { Yes }\end{array}$ \\
\hline Sigma & $\begin{array}{l}3.520^{* * *} \\
(0.050)\end{array}$ & $\begin{array}{l}3.506^{* * *} \\
(0.050)\end{array}$ & $\begin{array}{l}3.499 * * * \\
(0.051)\end{array}$ & $\begin{array}{l}3.505^{* * *} \\
(0.051)\end{array}$ & $\begin{array}{l}3.098^{* * *} \\
(0.052)\end{array}$ & $\begin{array}{l}3.071 * * * \\
(0.052)\end{array}$ & $\begin{array}{l}3.037 * * * \\
(0.051)\end{array}$ \\
\hline $\mathrm{N}$ & 25541 & 25039 & 24702 & 25055 & 19440 & 18826 & 18826 \\
\hline
\end{tabular}

Notes: This table reports the regression results of tax adjustment after the audit (as percent of the firm's revenue) on the corruption index of the owner's home country. A key variable is the interaction term between CPI and the firm's total asset. Column (2) through (6) report different robustness checks. The country fixed effected model reported in Column 7 is linear because the Tobit fixed effect estimator is not available. To deal with outliers, monetary variables have been $90 \%$ Winsorized. All specifications include year dummies and a constant. Robust standard errors are in parentheses. ${ }^{*} \mathrm{p}<0.10,{ }^{* *} \mathrm{p}<0.05,{ }^{* * *}$ $\mathrm{p}<.01$ 
Table 5. Estimation of Relationship Between Corruption Index and Audit Adjustment Allowing Effect to Differ by Firm Size, Controlling for Corporate Tax Rate Differentials

\begin{tabular}{|c|c|c|c|c|}
\hline & $\begin{array}{c}\text { Tax Rate Diff } \\
(1) \\
\end{array}$ & $\begin{array}{c}\text { Interact with } \\
\text { Corruption } \\
\text { Perceptions Index } \\
(2) \\
\end{array}$ & $\begin{array}{l}\text { Interact with } \\
\text { Worldwide Tax } \\
\text { System } \\
\text { (3) } \\
\end{array}$ & $\begin{array}{c}\text { Interact with } \\
\text { Tax Haven } \\
(4) \\
\end{array}$ \\
\hline Corruption Index (CPI) & $\begin{array}{l}0.952^{* * *} \\
(0.145)\end{array}$ & $\begin{array}{l}0.940^{* * *} \\
(0.146)\end{array}$ & $\begin{array}{l}0.839 * * * \\
(0.158)\end{array}$ & $\begin{array}{l}0.963^{* * *} \\
(0.152)\end{array}$ \\
\hline $\mathrm{CPI}{ }^{*} \ln ($ Total Assets) & $\begin{array}{l}-0.051^{* * *} \\
(0.008)\end{array}$ & $\begin{array}{l}-0.051^{* * *} \\
(0.008)\end{array}$ & $\begin{array}{l}-0.049 * * * \\
(0.009)\end{array}$ & $\begin{array}{l}-0.052^{* * *} \\
(0.009)\end{array}$ \\
\hline $\ln$ (Total Assets) & $\begin{array}{l}0.042^{*} \\
(0.024)\end{array}$ & $\begin{array}{l}0.042^{*} \\
(0.024)\end{array}$ & $\begin{array}{l}0.062 * * \\
(0.025)\end{array}$ & $\begin{array}{l}0.067 * * * \\
(0.026)\end{array}$ \\
\hline DIF Score & $\begin{array}{l}-0.000 * \\
(0.000)\end{array}$ & $\begin{array}{l}-0.000^{*} \\
(0.000)\end{array}$ & $\begin{array}{l}-0.000 \\
(0.000)\end{array}$ & $\begin{array}{l}-0.000 \\
(0.000)\end{array}$ \\
\hline Public & $\begin{array}{l}-0.196 * * \\
(0.087)\end{array}$ & $\begin{array}{l}-0.195^{* *} \\
(0.087)\end{array}$ & $\begin{array}{l}-0.154 \\
(0.160)\end{array}$ & $\begin{array}{l}-0.137 \\
(0.160)\end{array}$ \\
\hline Multinational & $\begin{array}{l}0.183^{* * *} \\
(0.061)\end{array}$ & $\begin{array}{l}0.184^{* * *} \\
(0.061)\end{array}$ & $\begin{array}{l}0.280^{* * *} \\
(0.075)\end{array}$ & $\begin{array}{l}0.270 * * * \\
(0.075)\end{array}$ \\
\hline Tax Rate Diff (US-Foreign) & $\begin{array}{l}0.012^{* *} \\
(0.006)\end{array}$ & $\begin{array}{l}0.037 \\
(0.039)\end{array}$ & $\begin{array}{l}0.123 * * \\
(0.053)\end{array}$ & $\begin{array}{l}0.009 \\
(0.041)\end{array}$ \\
\hline Tax Rate Diff*CPI & & $\begin{array}{l}-0.003 \\
(0.005)\end{array}$ & $\begin{array}{l}-0.014 * * \\
(0.007)\end{array}$ & $\begin{array}{l}-0.000 \\
(0.005)\end{array}$ \\
\hline Worldwide Tax Regime & & & $\begin{array}{l}-0.381 * * \\
(0.163)\end{array}$ & \\
\hline Tax Rate Diff*Worldwide & & & $\begin{array}{l}-0.046^{* *} \\
(0.019)\end{array}$ & \\
\hline Worldwide*CPI & & & $\begin{array}{l}0.127 * * \\
(0.054)\end{array}$ & \\
\hline Tax Haven & & & & $\begin{array}{l}-0.387^{*} \\
(0.210)\end{array}$ \\
\hline Tax Rate Diff*Tax Haven & & & & $\begin{array}{l}0.010 \\
(0.016)\end{array}$ \\
\hline Tax Haven*CPI & & & & $\begin{array}{l}0.312^{* * *} \\
(0.112)\end{array}$ \\
\hline Industry Dummies & Yes & & Yes & Yes \\
\hline Year Dummies & Yes & & Yes & Yes \\
\hline Sigma & $\begin{array}{l}3.479 * * * \\
(0.051)\end{array}$ & $\begin{array}{l}3.479 * * * \\
(0.051)\end{array}$ & $\begin{array}{l}3.653 * * * \\
(0.058)\end{array}$ & $\begin{array}{l}3.654 * * * \\
(0.058)\end{array}$ \\
\hline $\mathrm{N}$ & 24858 & 24858 & 19835 & 19835 \\
\hline
\end{tabular}

Notes: This table reports the regression results of tax adjustment after the audit (as percent of the firm's revenue) on the corruption index of the owner's home country. The key control variables are the characteristics of the corporate tax system in the owner's country, including the rate difference with the US, whether it belongs to the Worldwide Tax System, an if it is a Tax Heaven.To deal with outliers, monetary variables have been 90\% Winsorized. All specifications include year dummies and a constant. Robust standard errors are in parentheses. * $\mathrm{p}<0.10,{ }^{* *} \mathrm{p}<0.05, * * * \mathrm{p}<.01$ 
Table 6. Estimation of Relationship Between World Bank's Control of Corruption Indicator and Audit Adjustment - Allowing Effect to Differ by Firm Size, With Robustness Checks

\begin{tabular}{|c|c|c|c|c|c|c|}
\hline & $\begin{array}{c}\text { Base } \\
(1) \\
\end{array}$ & $\begin{array}{c}\text { With GDP } \\
(2) \\
\end{array}$ & $\begin{array}{c}\text { With Trade } \\
\text { (3) }\end{array}$ & $\begin{array}{c}\text { With Dist } \\
\text { (4) }\end{array}$ & $\begin{array}{c}\text { With Income } \\
\text { (5) }\end{array}$ & $\begin{array}{c}\text { With All } \\
(6)\end{array}$ \\
\hline Control of Corr. Indicator (CCI) & $\begin{array}{l}1.855^{* * *} \\
(0.285)\end{array}$ & $\begin{array}{l}2.448^{* * *} \\
(0.406)\end{array}$ & $\begin{array}{l}1.971^{* * *} \\
(0.308)\end{array}$ & $\begin{array}{l}1.973^{* * *} \\
(0.290)\end{array}$ & $\begin{array}{l}1.637^{* * *} \\
(0.306)\end{array}$ & $\begin{array}{l}1.926^{* * *} \\
(0.453)\end{array}$ \\
\hline CCI* $\ln ($ Total Assets $)$ & $\begin{array}{l}-0.101 * * * \\
(0.017)\end{array}$ & $\begin{array}{l}-0.148^{* * *} \\
(0.023)\end{array}$ & $\begin{array}{l}-0.107 * * * \\
(0.018)\end{array}$ & $\begin{array}{l}-0.104^{* * *} \\
(0.017)\end{array}$ & $\begin{array}{l}-0.088^{* * *} \\
(0.018)\end{array}$ & $\begin{array}{l}-0.109 * * * \\
(0.025)\end{array}$ \\
\hline $\ln$ (Total Assets) & $\begin{array}{l}0.019 \\
(0.021)\end{array}$ & $\begin{array}{l}1.423 * * * \\
(0.375)\end{array}$ & $\begin{array}{l}-0.080^{* *} \\
(0.035)\end{array}$ & $\begin{array}{l}-0.571^{* * *} \\
(0.144)\end{array}$ & $\begin{array}{l}-0.387 * * * \\
(0.077)\end{array}$ & $\begin{array}{l}-0.068 \\
(0.471)\end{array}$ \\
\hline DIF Score & $\begin{array}{l}-0.000^{*} \\
(0.000)\end{array}$ & $\begin{array}{l}-0.000 * * \\
(0.000)\end{array}$ & $\begin{array}{l}-0.000^{* *} \\
(0.000)\end{array}$ & $\begin{array}{l}-0.000^{*} \\
(0.000)\end{array}$ & $\begin{array}{l}-0.000^{*} \\
(0.000)\end{array}$ & $\begin{array}{l}-0.000^{*} \\
(0.000)\end{array}$ \\
\hline Public & $\begin{array}{l}-0.209 * * \\
(0.087)\end{array}$ & $\begin{array}{l}-0.189 * * \\
(0.087)\end{array}$ & $\begin{array}{l}-0.050 \\
(0.090)\end{array}$ & $\begin{array}{l}-0.133 \\
(0.088)\end{array}$ & $\begin{array}{l}-0.258^{* * *} \\
(0.087)\end{array}$ & $\begin{array}{l}-0.110 \\
(0.089)\end{array}$ \\
\hline Multinational & $\begin{array}{l}0.188^{* * *} \\
(0.062)\end{array}$ & $\begin{array}{l}0.197 * * * \\
(0.062)\end{array}$ & $\begin{array}{l}0.203^{* * *} \\
(0.062)\end{array}$ & $\begin{array}{l}0.175^{* * *} \\
(0.062)\end{array}$ & $\begin{array}{l}0.038 \\
(0.062)\end{array}$ & $\begin{array}{l}0.044 \\
(0.062)\end{array}$ \\
\hline Foreign Controlled Corp. & $\begin{array}{l}-0.336^{* * *} \\
(0.078)\end{array}$ & $\begin{array}{l}-0.574 * * * \\
(0.089)\end{array}$ & $\begin{array}{l}-0.556^{*} \\
(0.291)\end{array}$ & $\begin{array}{l}-0.090 \\
(0.116)\end{array}$ & $\begin{array}{l}-0.189 * * \\
(0.077)\end{array}$ & $\begin{array}{l}0.711^{*} \\
(0.386)\end{array}$ \\
\hline $\ln$ (GDP Per Capita) & & $\begin{array}{l}1.677 * * * \\
(0.602)\end{array}$ & & & & $\begin{array}{l}0.803 \\
(0.703)\end{array}$ \\
\hline $\ln ($ GDP PC* $\ln$ (Total Assets) & & $\begin{array}{l}-0.132^{* * *} \\
(0.035)\end{array}$ & & & & $\begin{array}{l}-0.066 \\
(0.041)\end{array}$ \\
\hline $\ln ($ Trade $)$ & & & $\begin{array}{l}-0.184 * * * \\
(0.054)\end{array}$ & & & $\begin{array}{l}-0.186^{* * *} \\
(0.067)\end{array}$ \\
\hline $\ln (\text { Trade })^{*} \ln ($ Total Assets $)$ & & & $\begin{array}{l}0.011^{* * *} \\
(0.003)\end{array}$ & & & $\begin{array}{l}0.007 * * \\
(0.003)\end{array}$ \\
\hline $\ln ($ Distance $)$ & & & & $\begin{array}{l}-1.508^{* * *} \\
(0.300)\end{array}$ & & $\begin{array}{l}-0.979 * * * \\
(0.357)\end{array}$ \\
\hline $\ln ($ Distance $) * \ln ($ Total Assets $)$ & & & & $\begin{array}{l}0.071 * * * \\
(0.017)\end{array}$ & & $\begin{array}{l}0.037^{*} \\
(0.020)\end{array}$ \\
\hline $\ln ($ Net Income $)$ & & & & & $\begin{array}{l}-0.627 * * * \\
(0.084)\end{array}$ & $\begin{array}{l}-0.636^{* * *} \\
(0.088)\end{array}$ \\
\hline $\ln (\text { Net Income })^{*} \ln ($ Total Assets $)$ & & & & & $\begin{array}{l}0.033^{* * *} \\
(0.005)\end{array}$ & $\begin{array}{l}0.034^{* * *} \\
(0.005)\end{array}$ \\
\hline Industry Dummies & Yes & Yes & Yes & Yes & Yes & Yes \\
\hline Year Dummies & Yes & Yes & Yes & Yes & Yes & Yes \\
\hline Sigma & $\begin{array}{l}3.520 * * * \\
(0.050)\end{array}$ & $\begin{array}{l}3.505^{* * *} \\
(0.051)\end{array}$ & $\begin{array}{l}3.498^{* * *} \\
(0.051)\end{array}$ & $\begin{array}{l}3.505^{* * *} \\
(0.051)\end{array}$ & $\begin{array}{l}3.107^{* * *} \\
(0.052)\end{array}$ & $\begin{array}{l}3.098^{* * *} \\
(0.052)\end{array}$ \\
\hline $\mathrm{N}$ & 25539 & 25039 & 24702 & 25055 & 19439 & 18826 \\
\hline
\end{tabular}

Notes: This table reports the regression results of tax adjustment after the audit (as percent of the firm's revenue) on the corruption index of the owner's home country. A key variable is the interaction term between World Bank's Control of Corruption Indicator and the firm's total asset. Column (2) through (6) report different robustness checks. To deal with outliers, monetary variables have been $90 \%$ Winsorized. All specifications include year dummies and a constant. Robust standard errors are in parentheses. ${ }^{*} \mathrm{p}<0.10,{ }^{* *} \mathrm{p}<0.05,{ }^{* * *} \mathrm{p}<.01$ 
Table 7. Robusness Check Using Alternate Estimators

\begin{tabular}{|c|c|c|c|}
\hline & $\begin{array}{c}\text { OLS } \\
(1) \\
\end{array}$ & $\begin{array}{c}\text { Linear } \\
\text { Between Effects } \\
(2) \\
\end{array}$ & $\begin{array}{c}\text { Probit } \\
(3) \\
\end{array}$ \\
\hline Corruption Index (CPI) & $\begin{array}{l}0.418^{* * *} \\
(0.074)\end{array}$ & $\begin{array}{l}0.413^{* * *} \\
(0.062)\end{array}$ & $\begin{array}{l}0.121 * * * \\
(0.030)\end{array}$ \\
\hline $\mathrm{CPI} * \ln ($ Total Assets $)$ & $\begin{array}{c}-0.022^{* * *} \\
(0.004)\end{array}$ & $\begin{array}{l}-0.023^{* * *} \\
(0.004)\end{array}$ & $\begin{array}{l}-0.007 * * * \\
(0.002)\end{array}$ \\
\hline $\ln$ (Total Assets) & $\begin{array}{l}-0.043 * * * \\
(0.012)\end{array}$ & $\begin{array}{l}-0.047 * * * \\
(0.013)\end{array}$ & $\begin{array}{l}0.045^{* * *} \\
(0.006)\end{array}$ \\
\hline DIF Score & $\begin{array}{l}-0.000 * * * \\
(0.000)\end{array}$ & $\begin{array}{l}-0.000^{* * *} \\
(0.000)\end{array}$ & $\begin{array}{l}0.000 \\
(0.000)\end{array}$ \\
\hline Industry Dummies & Yes & Yes & Yes \\
\hline Year Dummies & Yes & Yes & Yes \\
\hline R-squared & 0.032 & - & - \\
\hline $\mathrm{N}$ & 25541 & 25541 & 25541 \\
\hline \multicolumn{4}{|c|}{$\begin{array}{l}\text { Notes: This table summarizes the estimation results using alternative estimators. These } \\
\text { specifications are based on our main specification reported in Table 4's Column (1), which uses a } \\
\text { Tobit estimator. The alternative estimators used in this table are: (i) OLS; (ii) Panel data random- } \\
\text { effects; and (ii) Panel data between-effects. Data from 1996-2007 Audit Information Management } \\
\text { System merged with corporate tax returns. All dollar values are in constant } 2009 \$ \text {. To deal with } \\
\text { outliers, monetary variables have been } 90 \% \text { Winsorized. All specifications include year dummies } \\
\text { and a constant. Robust standard errors are in parentheses. }{ }^{*} \mathrm{p}<0.10,{ }^{* *} \mathrm{p}<0.05,{ }^{* * *} \mathrm{p}<.01\end{array}$} \\
\hline
\end{tabular}


Table 8. Robusness Checks Using Different Winsorization Windows

\begin{tabular}{|c|c|c|c|c|c|}
\hline & $1 \%$ & $3 \%$ & $5 \%$ & $10 \%$ & No Winsor \\
\hline Corruption Index (CPI) & $\begin{array}{l}1.633^{* * *} \\
(0.308)\end{array}$ & $\begin{array}{l}1.010^{* * *} \\
(0.169)\end{array}$ & $\begin{array}{l}0.756^{* * *} \\
(0.125)\end{array}$ & $\begin{array}{l}0.402^{* * *} \\
(0.074)\end{array}$ & $\begin{array}{l}207.367^{* * *} \\
(80.106)\end{array}$ \\
\hline CPI*ln(Total Assets) & $\begin{array}{l}-0.087 * * * \\
(0.018)\end{array}$ & $\begin{array}{l}-0.054 * * * \\
(0.010)\end{array}$ & $\begin{array}{l}-0.041 * * * \\
(0.007)\end{array}$ & $\begin{array}{l}-0.022 * * * \\
(0.004)\end{array}$ & $\begin{array}{l}-10.815^{* *} \\
(4.289)\end{array}$ \\
\hline $\ln$ (Total Assets) & $\begin{array}{l}0.117 * * \\
(0.051)\end{array}$ & $\begin{array}{l}0.052^{*} \\
(0.030)\end{array}$ & $\begin{array}{l}0.022 \\
(0.023)\end{array}$ & $\begin{array}{l}-0.003 \\
(0.014)\end{array}$ & $\begin{array}{l}69.350^{* * *} \\
(23.002)\end{array}$ \\
\hline DIF Score & $\begin{array}{l}-0.001 \\
(0.000)\end{array}$ & $\begin{array}{l}-0.000 \\
(0.000)\end{array}$ & $\begin{array}{l}-0.000^{*} \\
(0.000)\end{array}$ & $\begin{array}{l}-0.000 \\
(0.000)\end{array}$ & $\begin{array}{l}0.061 \\
(0.074)\end{array}$ \\
\hline Public & $\begin{array}{l}-0.032 \\
(0.161)\end{array}$ & $\begin{array}{l}0.007 \\
(0.097)\end{array}$ & $\begin{array}{l}-0.196^{* *} \\
(0.087)\end{array}$ & $\begin{array}{l}0.012 \\
(0.042)\end{array}$ & $\begin{array}{l}4.161 \\
(38.756)\end{array}$ \\
\hline Multinational & $\begin{array}{l}0.465^{* * *} \\
(0.144)\end{array}$ & $\begin{array}{l}0.251 * * * \\
(0.082)\end{array}$ & $\begin{array}{l}0.189 * * * \\
(0.062)\end{array}$ & $\begin{array}{l}0.143^{* * *} \\
(0.034)\end{array}$ & $\begin{array}{l}127.078^{* *} \\
(53.851)\end{array}$ \\
\hline Foreign Controlled Corp. & $\begin{array}{l}-1.289 * \\
(0.729)\end{array}$ & $\begin{array}{l}-0.561 \\
(0.484)\end{array}$ & $\begin{array}{l}-0.335^{* * *} \\
(0.079)\end{array}$ & $\begin{array}{l}-0.287 \\
(0.204)\end{array}$ & $\begin{array}{l}-317.175 \\
(209.556)\end{array}$ \\
\hline Industry Dummies & Yes & Yes & Yes & Yes & Yes \\
\hline Year Dummies & Yes & Yes & Yes & Yes & Yes \\
\hline Sigma & $\begin{array}{l}8.274 * * * \\
(0.224)\end{array}$ & $\begin{array}{l}4.750^{* * *} \\
(0.083)\end{array}$ & $\begin{array}{l}3.520 * * * \\
(0.050)\end{array}$ & $\begin{array}{l}1.970^{* * *} \\
(0.020)\end{array}$ & $\begin{array}{l}2538.438^{* * *} \\
(827.892)\end{array}$ \\
\hline $\mathrm{N}$ & 25541 & 25541 & 25541 & 25541 & 25541 \\
\hline
\end{tabular}

Notes: This table summarizes the estimation results using Winsorization windows. The last column reports the results when no winsorization is conducted. These results are not reliable because the raw data includes some entry errors with extremely high values. Data from 1996-2007 Audit Information Management System merged with corporate tax returns. All dollar values are in constant 2009 \$. To deal with outliers, monetary variables have been $90 \%$ Winsorized. All specifications include year dummies and a constant. Robust standard errors are in parentheses. ${ }^{*} \mathrm{p}<0.10,{ }^{* *} \mathrm{p}<0.05,{ }^{* * *} \mathrm{p}<.01$ 


\section{Table 9. Robusness Check Using Foreign Owned Firms Only, and Corruption Measure of Country of Incoporation}

\begin{tabular}{|c|c|c|c|}
\hline Corruption measure & $\begin{array}{c}\text { Corruption of } \\
\text { Country of Owner }\end{array}$ & $\begin{array}{r}\text { Cor } \\
\text { Country o }\end{array}$ & $\begin{array}{l}\text { of of } \\
\text { orporation }\end{array}$ \\
\hline Sample & $\begin{array}{c}\text { Both U.S. and } \\
\text { foreign owned firms }\end{array}$ & $\begin{array}{l}\text { Incorporated } \\
\text { anywhere }\end{array}$ & $\begin{array}{c}\text { Incorporated } \\
\text { outside US }\end{array}$ \\
\hline Corr Index (CPI) & $\begin{array}{l}0.518^{* * *} \\
(0.131)\end{array}$ & $\begin{array}{l}-0.193 \\
(0.437)\end{array}$ & $\begin{array}{l}1.966^{*} \\
(1.020)\end{array}$ \\
\hline CPI * $\ln$ (Total Assets) & $\begin{array}{l}-0.031 * * * \\
(0.008)\end{array}$ & $\begin{array}{l}0.030 \\
(0.023)\end{array}$ & $\begin{array}{l}-0.093 * \\
(0.053)\end{array}$ \\
\hline $\ln$ (Total Assets) & $\begin{array}{l}-0.276^{* * *} \\
(0.020)\end{array}$ & $\begin{array}{l}-0.458^{* * *} \\
(0.057)\end{array}$ & $\begin{array}{l}0.210 \\
(0.212)\end{array}$ \\
\hline Public & $\begin{array}{l}0.315^{* * *} \\
(0.035)\end{array}$ & $\begin{array}{l}0.417^{* * *} \\
(0.052)\end{array}$ & $\begin{array}{l}-24.972 \\
(.)\end{array}$ \\
\hline Industry Dummies & Yes & Yes & Yes \\
\hline Year Dummies & Yes & Yes & Yes \\
\hline Sigma & $\begin{array}{l}4.293 * * * \\
(0.013)\end{array}$ & $\begin{array}{l}4.675^{* * *} \\
(0.017)\end{array}$ & $\begin{array}{l}4.369 * * * \\
(0.359)\end{array}$ \\
\hline $\mathrm{N}$ & 261,871 & 162,821 & 585 \\
\hline
\end{tabular}

Notes: This table summarizes the estimation results using different samples. Column (1) reports the estimation for the full sample of both US- and foreign-controlled firms. This column uses the corruption of the country of the owner. In constrast, Column (2) and (3) use corruption norms of the country of incorporation. The All column includes $1120 \mathrm{~F}$ and 1120 filers. Note the number of obs in Column (2) and (3) is less than in Column (1) because the CDW only has $1120 \mathrm{~F}$ filers from 2002 on. This subsample is almost all US incorporated firms. The dominance of US incorporated firms (who get the corruption index of the US, regardless of owner) overwhelm what variation there is in the country of foreign incorporation. Data from 1996-2007 Audit Information Management System merged with corporate tax returns. All dollar values are in constant 2009 \$. To deal with outliers, monetary variables have been $90 \%$ Winsorized. All specifications include year dummies and a constant. Robust standard errors are in parentheses. ${ }^{*} \mathrm{p}<0.10,{ }^{* *} \mathrm{p}<0.05,{ }^{* * *} \mathrm{p}<.01$ 
Table 10. Effect of Enforcement Measures on Tax Evasion by Firms with Different Corruption Norms

\begin{tabular}{|c|c|c|c|c|c|}
\hline & \multicolumn{3}{|c|}{ Enforcement Initiatives } & \multicolumn{2}{|c|}{ Audit Rates } \\
\hline & $(1)$ & $(2)$ & (3) & $(4)$ & $(5)$ \\
\hline Corruption Index (CPI) & $\begin{array}{l}0.779 * * * \\
(0.126)\end{array}$ & $\begin{array}{l}0.778^{* * *} \\
(0.128)\end{array}$ & $\begin{array}{l}0.798^{* * *} \\
(0.128)\end{array}$ & $\begin{array}{l}0.799 * * * \\
(0.132)\end{array}$ & $\begin{array}{l}0.762 * * * \\
(0.130)\end{array}$ \\
\hline $\mathrm{CPI} * \ln ($ Total Assets $)$ & $\begin{array}{l}-0.042^{* * *} \\
(0.007)\end{array}$ & $\begin{array}{l}-0.044 * * * \\
(0.008)\end{array}$ & $\begin{array}{l}-0.045^{* * *} \\
(0.008)\end{array}$ & $\begin{array}{l}-0.046^{* * *} \\
(0.008)\end{array}$ & $\begin{array}{l}-0.042^{* * *} \\
(0.008)\end{array}$ \\
\hline $\ln$ (Total Assets) & $\begin{array}{l}0.026 \\
(0.023)\end{array}$ & $\begin{array}{l}0.081 * * * \\
(0.026)\end{array}$ & $\begin{array}{l}0.086^{* * *} \\
(0.026)\end{array}$ & $\begin{array}{l}0.054 * * \\
(0.024)\end{array}$ & $\begin{array}{l}0.044 * \\
(0.024)\end{array}$ \\
\hline DIF Score & $\begin{array}{l}-0.000^{*} \\
(0.000)\end{array}$ & $\begin{array}{l}-0.000^{*} \\
(0.000)\end{array}$ & $\begin{array}{l}-0.000^{* *} \\
(0.000)\end{array}$ & $\begin{array}{l}-0.000^{*} \\
(0.000)\end{array}$ & $\begin{array}{l}-0.000^{*} \\
(0.000)\end{array}$ \\
\hline Public & $\begin{array}{l}-0.217^{* *} \\
(0.106)\end{array}$ & $\begin{array}{l}-0.237^{* * *} \\
(0.087)\end{array}$ & $\begin{array}{l}-0.261 * * \\
(0.106)\end{array}$ & $\begin{array}{l}-0.236^{* * *} \\
(0.087)\end{array}$ & $\begin{array}{l}-0.231 \text { *** } \\
(0.087)\end{array}$ \\
\hline Multinational & $\begin{array}{l}0.186^{* * *} \\
(0.062)\end{array}$ & $\begin{array}{l}0.186^{* * *} \\
(0.062)\end{array}$ & $\begin{array}{l}0.175^{* * *} \\
(0.063)\end{array}$ & $\begin{array}{l}0.186^{* * *} \\
(0.062)\end{array}$ & $\begin{array}{l}0.187 * * * \\
(0.062)\end{array}$ \\
\hline Foreign Controlled Corp. & $\begin{array}{l}-0.336^{* * * *} \\
(0.079)\end{array}$ & $\begin{array}{l}-0.336^{* * *} \\
(0.079)\end{array}$ & $\begin{array}{l}-0.325^{* * *} \\
(0.078)\end{array}$ & $\begin{array}{l}-0.327 * * * \\
(0.078)\end{array}$ & $\begin{array}{l}-0.332^{* * *} \\
(0.078)\end{array}$ \\
\hline Sarbanes-Oxley & $\begin{array}{l}-0.936^{* *} \\
(0.435)\end{array}$ & & $\begin{array}{l}-0.910^{* *} \\
(0.118)\end{array}$ & & \\
\hline CPI*Sarbanes-Oxley & $\begin{array}{l}0.395^{* *} \\
(0.170)\end{array}$ & & $\begin{array}{l}0.385^{* *} \\
(0.169)\end{array}$ & & \\
\hline Total Assets $>=\$ 10 \mathrm{~mm}$ & & $\begin{array}{l}-0.351^{* * *} \\
(0.116)\end{array}$ & $\begin{array}{l}-0.348^{* * *} \\
(0.117)\end{array}$ & & \\
\hline Schedule M-3 & & $\begin{array}{l}-0.549 * * * \\
(0.195)\end{array}$ & $\begin{array}{l}-0.546^{* * *} \\
(0.195)\end{array}$ & & \\
\hline CPI*Schedule M-3 & & $\begin{array}{l}0.113 * * \\
(0.046)\end{array}$ & $\begin{array}{l}0.109 * * \\
(0.046)\end{array}$ & & \\
\hline Audit Rate by Size & & & & $\begin{array}{l}-3.382^{* * *} \\
(0.806)\end{array}$ & \\
\hline CPI* Audit Rate by Size & & & & $\begin{array}{l}0.570^{*} \\
(0.303)\end{array}$ & \\
\hline Audit Rate by Size and State & & & & & $\begin{array}{l}-2.204^{* * *} \\
(0.651)\end{array}$ \\
\hline CPI*Audit Rate by Size and State & & & & & $\begin{array}{l}0.229 \\
(0.238)\end{array}$ \\
\hline Industry Dummies & Yes & Yes & Yes & Yes & Yes \\
\hline Year Dummies & Yes & Yes & Yes & Yes & Yes \\
\hline Sigma & $\begin{array}{l}3.520^{* * *} \\
(0.050)\end{array}$ & $\begin{array}{l}3.516^{* * *} \\
(0.050)\end{array}$ & $\begin{array}{l}3.515^{* * *} \\
(0.050)\end{array}$ & $\begin{array}{l}3.517 * * * \\
(0.050)\end{array}$ & $\begin{array}{l}3.517 * * * \\
(0.050)\end{array}$ \\
\hline $\mathrm{N}$ & 25541 & 25541 & 25541 & 25541 & 25541 \\
\hline
\end{tabular}

Notes: This table reports the regression results of tax adjustment after the audit (as percent of the firm's revenue) on the treatment of three IRS measures to fight tax evasion. The interaction of these treatments with CPI indicates the differential effect on firms with different corruption norms. Data from 1996-2007 Audit Information Management System merged with corporate tax returns. All dollar values are in constant 2009 \$. To deal with outliers, monetary variables have been $5 \%$ Winsorized. All specifications include year dummies and a constant. Robust standard errors are in parentheses. ${ }^{*} \mathrm{p}<0.10,{ }^{* *} \mathrm{p}<0.05,{ }^{* * *} \mathrm{p}<.01$ 
Table 11. Robusness Check Using Sub-samples

\begin{tabular}{|c|c|c|c|c|c|c|}
\hline & $\begin{array}{c}\text { Public Firms } \\
(1)\end{array}$ & $\begin{array}{l}\text { Non-public } \\
\text { Firms } \\
(2) \\
\end{array}$ & $\begin{array}{c}\text { Multinational } \\
\text { (3) }\end{array}$ & $\begin{array}{c}\text { U.S. } \\
\text { Operations } \\
\text { Only } \\
(4)\end{array}$ & $\begin{array}{c}\text { OECD } \\
\text { Owner } \\
(5) \\
\end{array}$ & $\begin{array}{c}\text { Non-OECD } \\
\text { Owner } \\
(6)\end{array}$ \\
\hline Corruption Index (CPI) & $\begin{array}{l}1.294 \\
(1.304)\end{array}$ & $\begin{array}{l}0.786^{* * *} \\
(0.131)\end{array}$ & $\begin{array}{l}1.467 * * * \\
(0.445)\end{array}$ & $\begin{array}{l}0.699 * * * \\
(0.148)\end{array}$ & $\begin{array}{l}0.886^{* * *} \\
(0.159)\end{array}$ & $\begin{array}{l}-0.063 \\
(0.325)\end{array}$ \\
\hline CPI* $\ln ($ Total Assets $)$ & $\begin{array}{l}-0.058 \\
(0.064)\end{array}$ & $\begin{array}{l}-0.043 * * * \\
(0.008)\end{array}$ & $\begin{array}{l}-0.075^{* * *} \\
(0.023)\end{array}$ & $\begin{array}{l}-0.038^{* * *} \\
(0.009)\end{array}$ & $\begin{array}{l}-0.050 * * * \\
(0.009)\end{array}$ & $\begin{array}{l}0.006 \\
(0.019)\end{array}$ \\
\hline $\ln$ (Total Assets) & $\begin{array}{l}0.291 * \\
(0.165)\end{array}$ & $\begin{array}{l}0.019 \\
(0.024)\end{array}$ & $\begin{array}{l}0.233^{* * *} \\
(0.055)\end{array}$ & $\begin{array}{l}-0.016 \\
(0.028)\end{array}$ & $\begin{array}{l}0.042^{*} \\
(0.025)\end{array}$ & $\begin{array}{l}-0.186^{*} \\
(0.101)\end{array}$ \\
\hline DIF Score & $\begin{array}{l}-0.000 \\
(0.000)\end{array}$ & $\begin{array}{l}-0.000 \\
(0.000)\end{array}$ & $\begin{array}{l}-0.000^{*} \\
(0.000)\end{array}$ & $\begin{array}{l}-0.000 \\
(0.000)\end{array}$ & $\begin{array}{l}-0.000 \\
(0.000)\end{array}$ & $\begin{array}{l}-0.001 \\
(0.001)\end{array}$ \\
\hline Industry Dummies & Yes & Yes & Yes & Yes & Yes & Yes \\
\hline Year Dummies & Yes & Yes & Yes & Yes & Yes & Yes \\
\hline Sigma & $\begin{array}{l}2.006^{* * *} \\
(0.119)\end{array}$ & $\begin{array}{l}3.710^{* * *} \\
(0.054)\end{array}$ & $\begin{array}{l}2.622 * * * \\
(0.088)\end{array}$ & $\begin{array}{l}3.874 * * * \\
(0.060)\end{array}$ & $\begin{array}{l}3.394 * * * \\
(0.053)\end{array}$ & $\begin{array}{l}4.429 * * * \\
(0.146)\end{array}$ \\
\hline $\mathrm{N}$ & 3093 & 22448 & 7258 & 18283 & 23080 & 2461 \\
\hline
\end{tabular}

Notes: This table summarizes the estimation results using various subsamples. These specifications are based on our main specification reported in Table 4's Column (1), which uses a Tobit estimator. Data from 1996-2007

Audit Information Management System merged with corporate tax returns. All dollar values are in constant 2009 $\$$. To deal with outliers, monetary variables have been $90 \%$ Winsorized. All specifications include year dummies and a constant. Robust standard errors are in parentheses. ${ }^{*} \mathrm{p}<0.10,{ }^{* *} \mathrm{p}<0.05,{ }^{* * *} \mathrm{p}<.01$ 
Figure 1. Corruption Perception Index Across the World

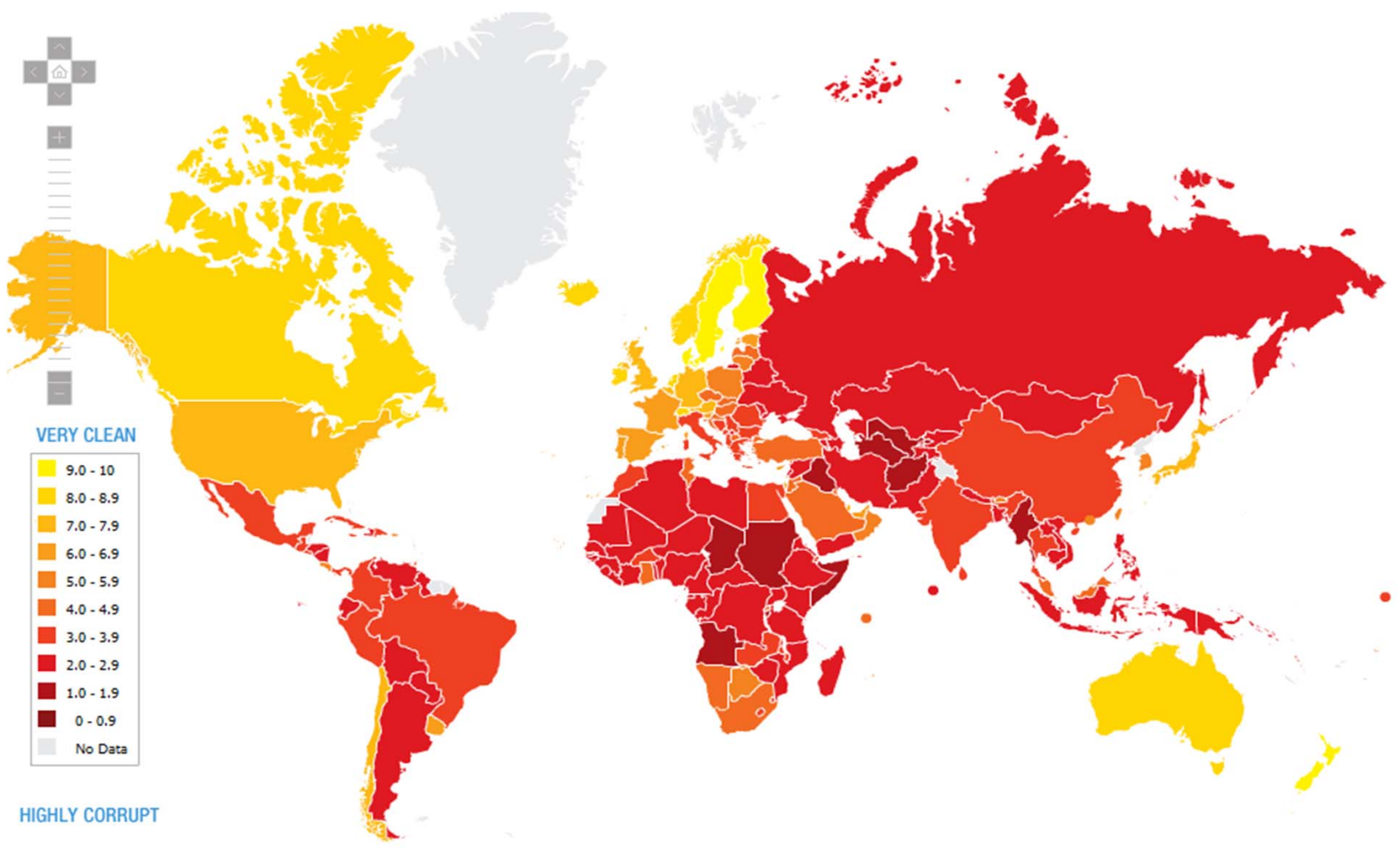


Figure 2. Tax Non-Compliance by Firm Size (Total Assets)

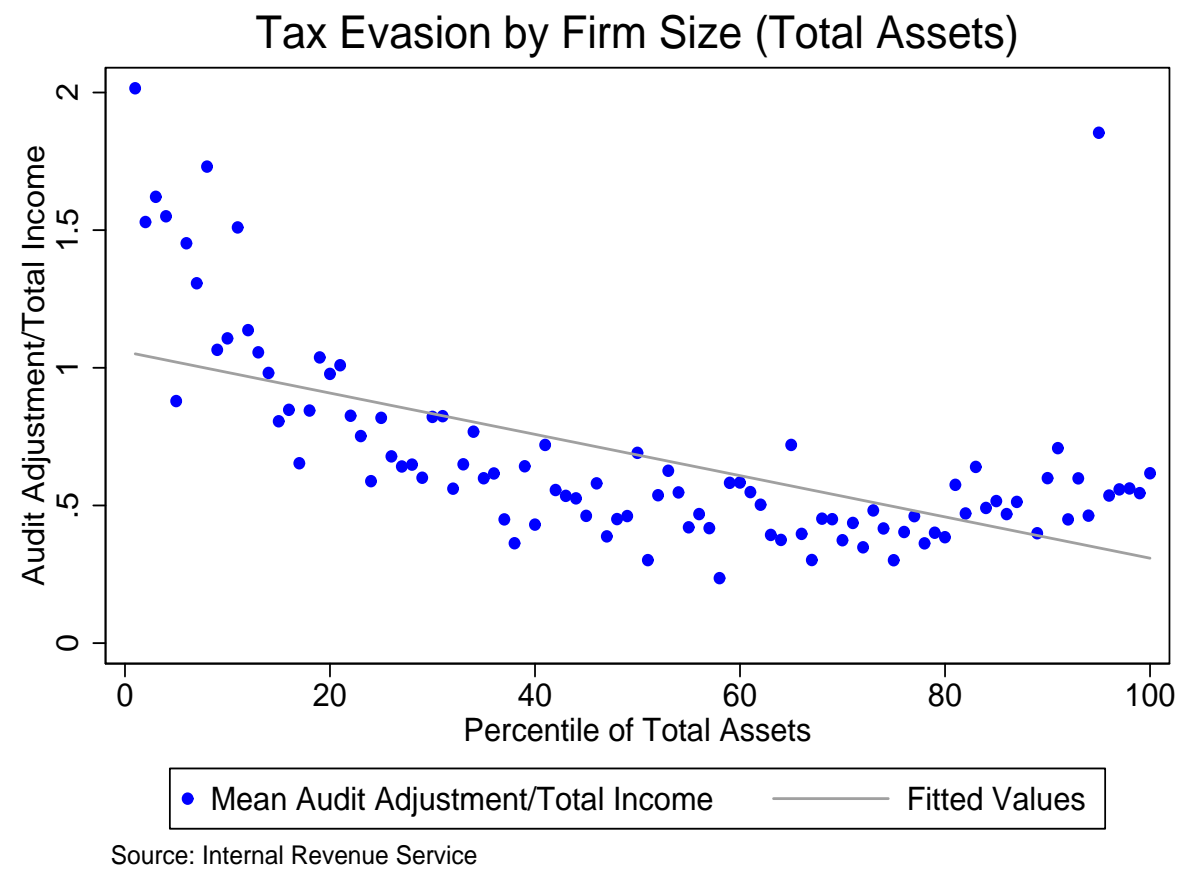

Notes: This figure shows the relationship between firms' size and tax evasion. Each dot represents a group of firms in a certain size percentile in terms of total assets. The height of the dot is the mean ratio of tax audit adjustment over total income for the percentile group. Data sources: Internal Revenue Service. 
Figure 3. Tax Non-Compliance and Corruption

Tax Evasion and Corruption

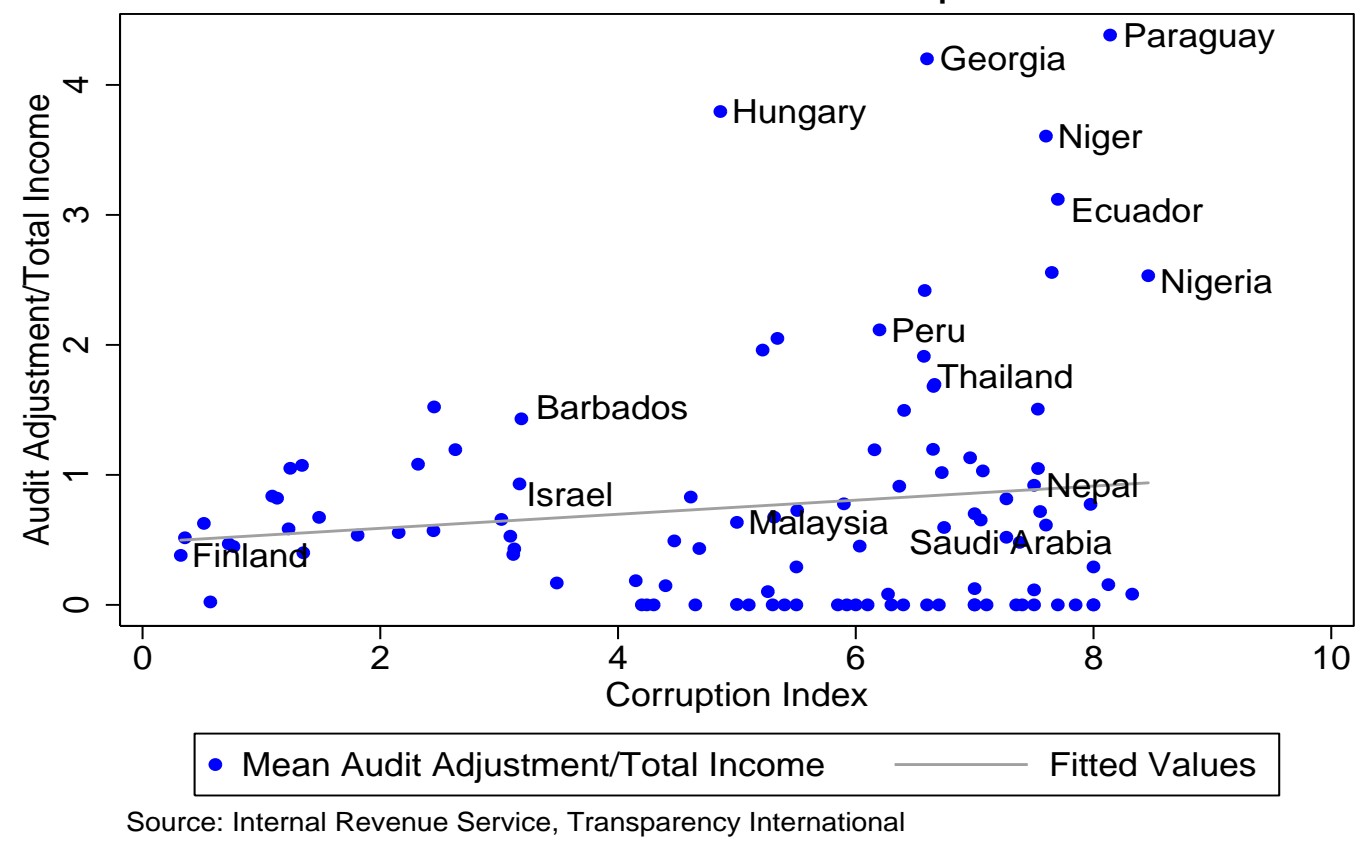

Notes: This figure shows the relationship between the home country's corruption of the owners and and tax evasion. Each dot represents a group of firms with owners from a certain country. The height of the dot is the mean ratio of tax audit adjustment over total income for the group of firms. Data sources: Internal Revenue Service and Transparency International 
Figure 4. Tax Non-Compliance and Corruption

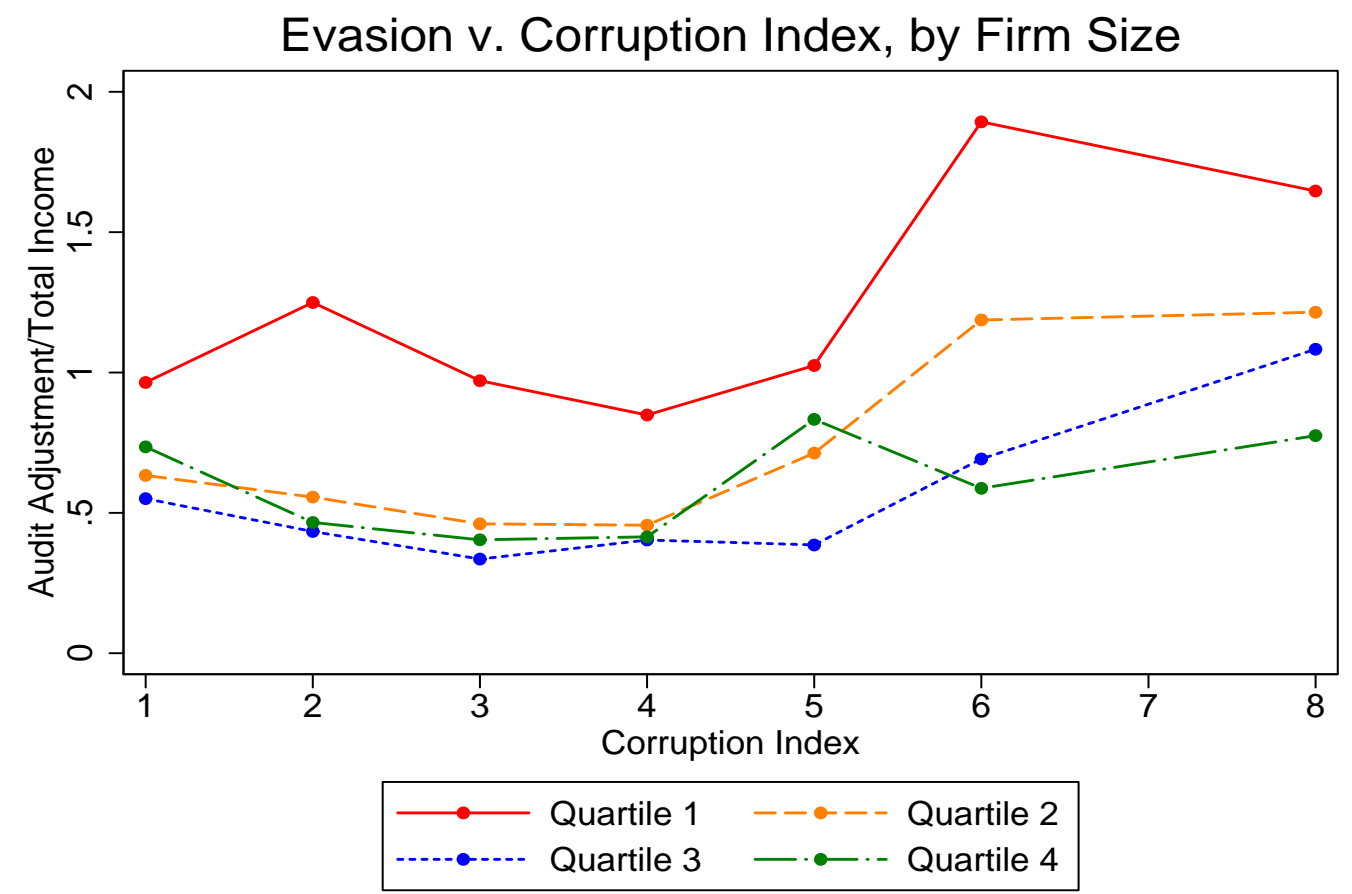

Notes: This figure shows the relationship between the corruption levels of the owners' home country and and tax evasion. Each line represents a firms in different quartiles, measured by total assets. The vertical axis is the mean ratio of tax audit adjustment over total income for the group of firms in a given size quartile and with owners whose countries have a certain level of corruption. Data sources: Internal Revenue Service and Transparency International 
Figure 5. Corruption, Firms' size and Tax Evasion

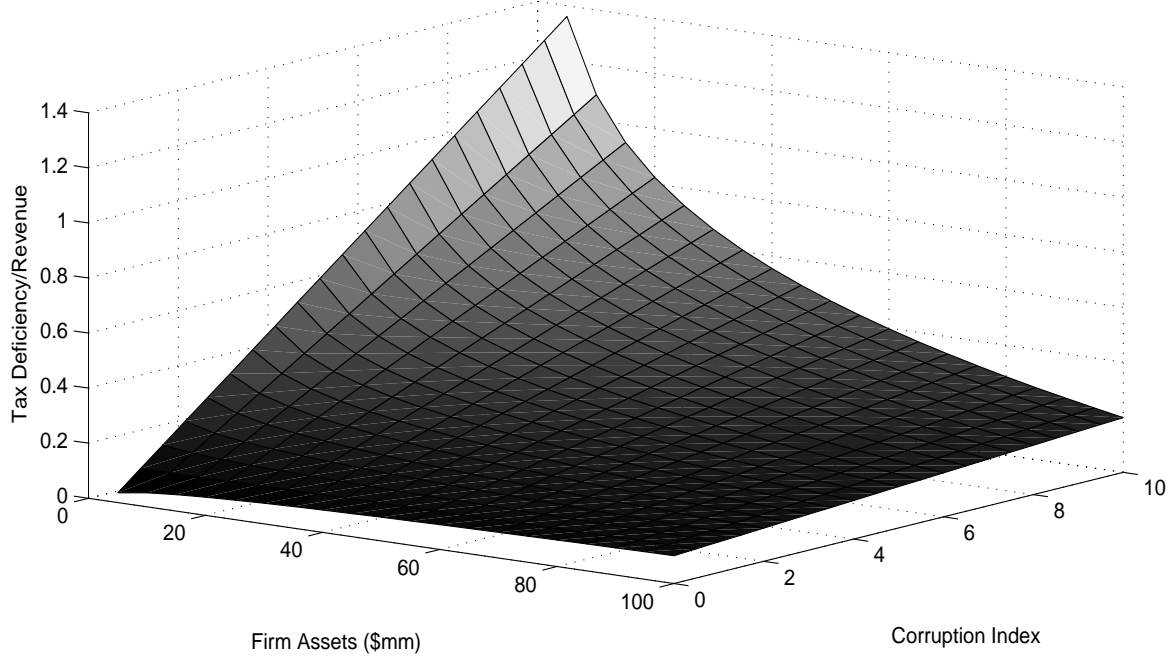

Notes: This figure shows the approximate relationship between the home country's corruption of the owners, firms' total assets, and predicted tax evasion. It helps to interpret the results of the regression analysis by demonstrating the interaction effect of onwers' corruption norms and firms' size. 